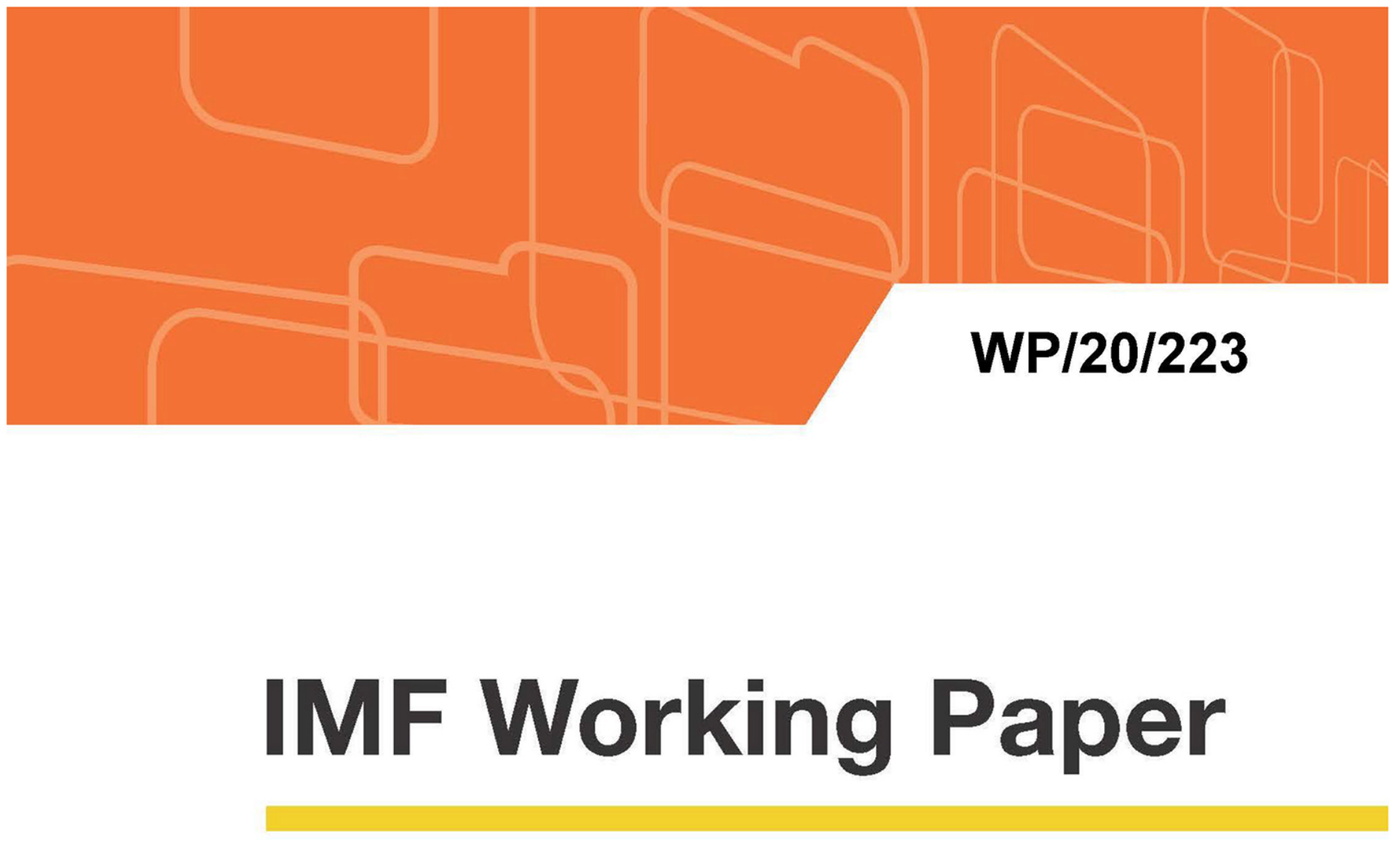

\title{
External Financing Dependence and Corporate Saving in ASEAN5
}

by Xin $\mathrm{Li}$

IMF Working Papers describe research in progress by the author(s) and are published to elicit comments and to encourage debate. The views expressed in IMF Working Papers are those of the author(s) and do not necessarily represent the views of the IMF, its Executive Board, or IMF management.

$$
\text { I N T E R N A T I O N A L M O N E T A R Y F U N D }
$$




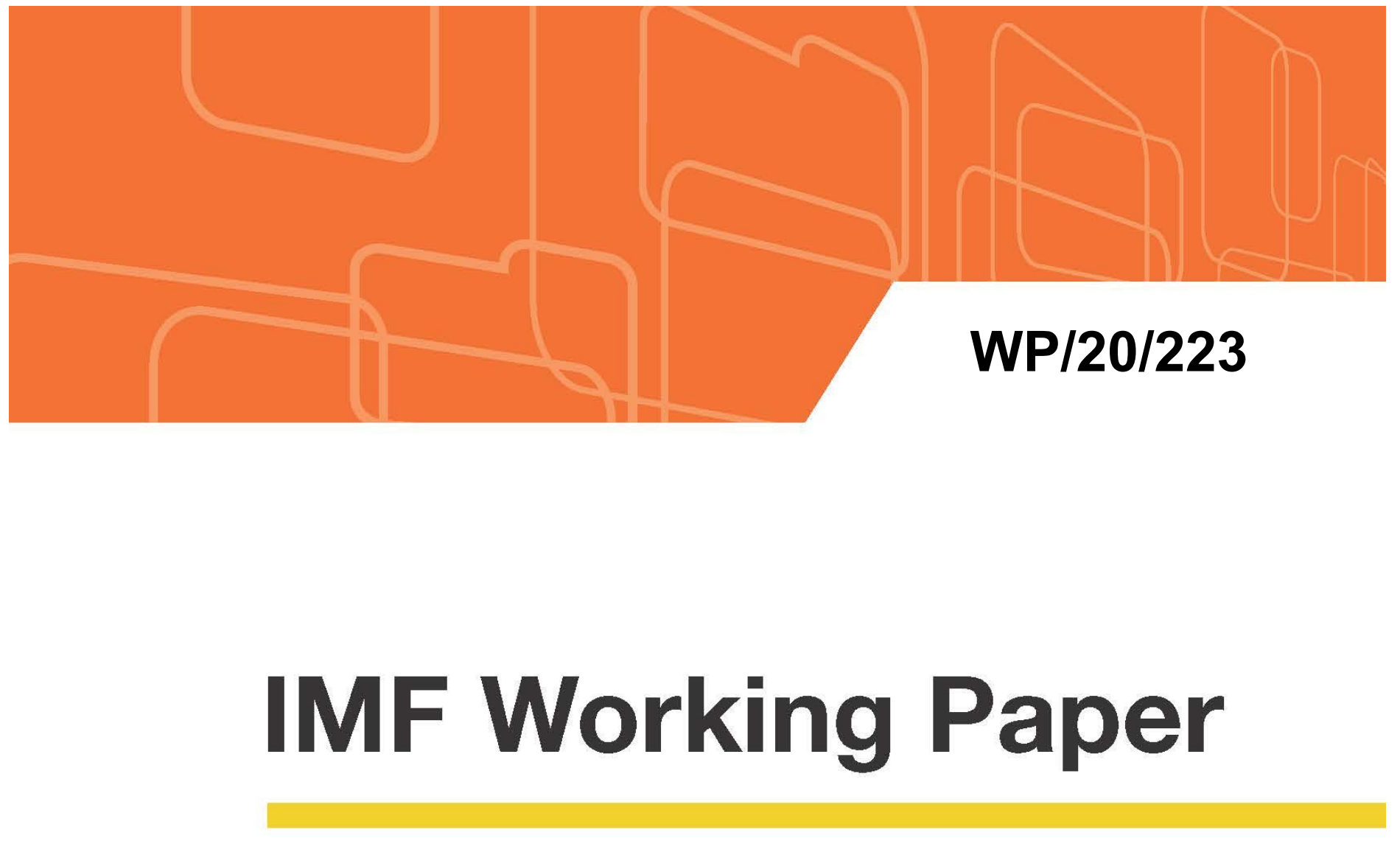

\section{External Financing Dependence and Corporate Saving in ASEAN5}

by $\mathrm{Xin} \mathrm{Li}$

IMF Working Papers describe research in progress by the author(s) and are published to elicit comments and to encourage debate. The views expressed in IMF Working Papers are those of the author(s) and do not necessarily represent the views of the IMF, its Executive Board, or IMF management.

$$
\text { I N T E R N A T | O N A L M O N E T A R Y F U N D }
$$




\title{
IMF Working Paper
}

Asia and Pacific Department

\section{External Financing Dependence and Corporate Saving in ASEAN5}

\author{
Prepared by Xin $\mathrm{Li}^{1}$
}

Authorized for distribution by Nada Choueiri

October 2020

\section{IMF Working Papers describe research in progress by the author(s) and are published to elicit comments and to encourage debate. The views expressed in IMF Working Papers are those of the author(s) and do not necessarily represent the views of the IMF, its Executive Board, or IMF management.}

\begin{abstract}
Using firm-level data on ASEAN5, this paper studies the differential effects of macrofinancial and structural factors on corporate saving behavior through the lens of external financing dependence. The finding suggests that non-financial corporations in ASEAN5 have been subject to binding financial constraints over the past two decades. Greater capital account openness or exchange rate depreciation reduces the average saving rate of industries with low dependence on external funds, while it increases the saving rate of industries with high dependence on external funds. The effects are greater for export-oriented industries. An improvement in banking sector competition, banks' lending efficiency, or policy clarity is associated with lower saving rate of firms across the board.

JEL Classification Numbers: F31, F32, F41, G30, G31.

Keywords: ASEAN countries, corporate saving, external financing need, exportorientation, financial constraint, capital account openness, exchange rate depreciation.
\end{abstract}

Author's E-Mail Address: xli4@imf.org

\footnotetext{
${ }^{1}$ This paper is prepared under the guidance of Nada Choueiri. I am grateful to Odd Per Brekk, Kenneth Kang, Jonathan Ostry, Tahsin Sedik, Katsiaryna Svirydzenka, and seminar participants at the IMF and Bank Negara Malaysia for their helpful comments.
} 


\section{Contents}

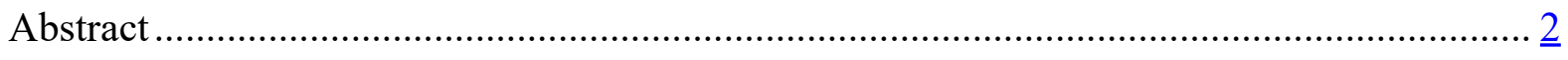

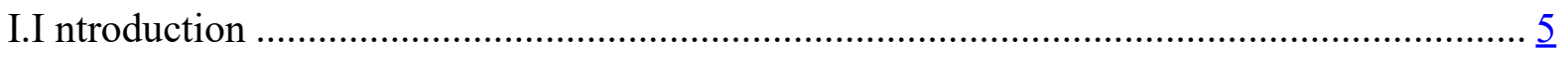

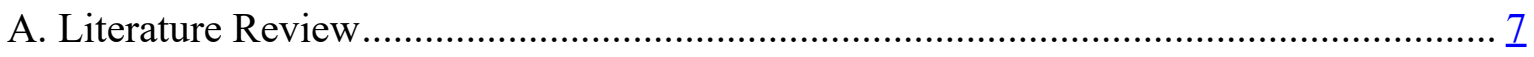

II. Data and Stylized Facts .......................................................................................... 9

A. Aggregate Stylized Facts …………………………........................................ 9

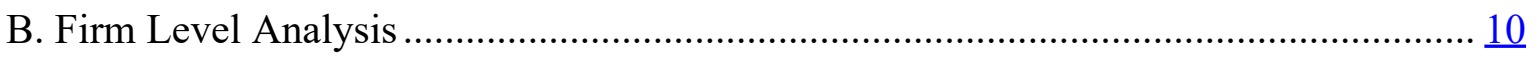

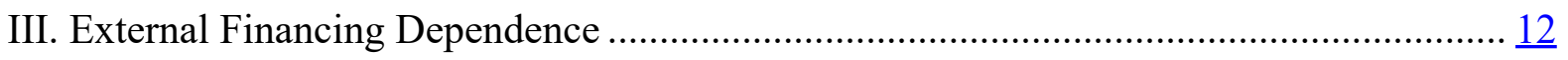

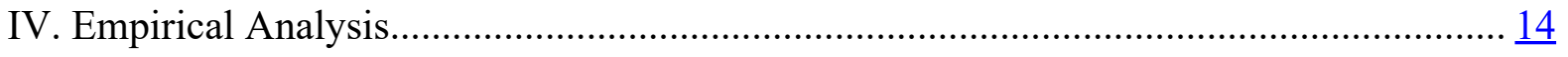

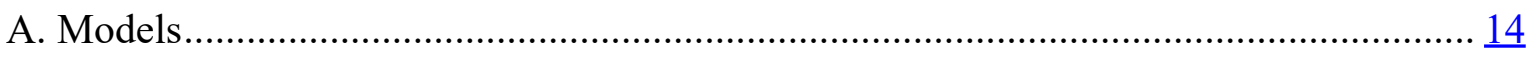

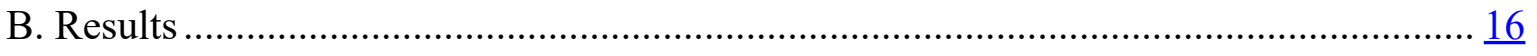

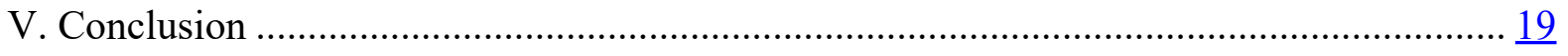

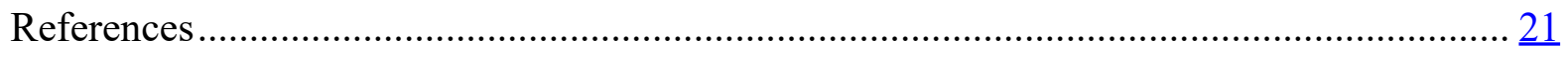

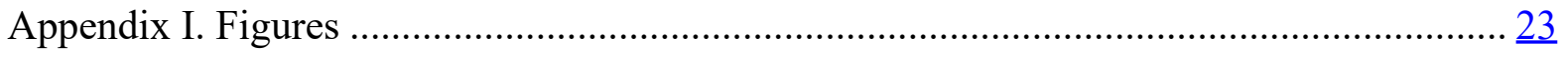

Figure A1. Corporate Saving in ASEAN5, 2000-2017 …………………………….... $\underline{23}$

Figure A2.1. U.S.: Net Saving by Industry ………………..................................... 24

Figure A2.2. ASEAN5: Net Saving by Industry …………………………………… 24

Figure A3.1. Export-Orientation of Manufacturing Industries in ASEAN5, 2006-2016 … $\underline{25}$

Figure A3.2. Export-Orientation of the Manufacturing Sector by Country, 2006-2016 … $\underline{25}$

Figure A4.1. Capital Account Openness, 2000-2017 ……………………………….... 26

Figure A4.2. Capital Account Openness in ASEAN5, 2000-2017 ……………………... 26

Figure A5. Exchange Rate Movements in ASEAN5, 2000-2018 ……………………... 27

Figure A6.1. Credit-to-GDP Ratio, 2000-2017 …………………………………..... $\underline{28}$

Figure A6.2. Credit-to-GDP Ratio in ASEAN5, 2000-2017 ………………………..... $\underline{28}$

Figure A6.3. Total Capitalization, 2000-2017 …………………………………….... 29

Figure A6.4. Spread between Lending and Deposit Rates, 2000-2017 ……………….... 29

Figure A6.5. Total Capitalization, 2000-2017 ……………………………………... $\underline{30}$

Figure A6.6. Concentration of the Largest Three Banks, 2000-2017 ............................... $\underline{30}$

Figure A7. Firm's Profit and Saving Trends ………………..................................... $\underline{31}$

Figure A8. USA: External Financing Dependence by Age (Number of years since IPO). $\underline{31}$

Figure A9. Choice between NYSE and NASDAQ …………………………………... $\underline{32}$

Figure A10. External Financing Dependence by Industry ............................................. $\underline{32}$

Figure A11. USA: Evolution of External Financing Dependence by Industry …………... $\underline{33}$

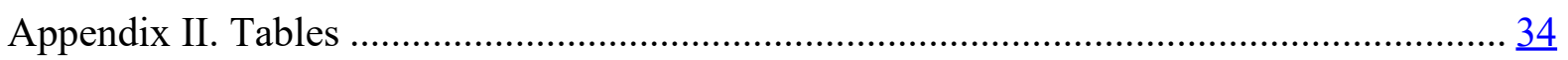


Table A1: Data Coverage................................................................................ 34

Table A2: Firm growth and Financial System Development ….................................. 35

Table A3: Firm/industry Characteristics and Net Saving ......................................... $\underline{36}$

Table A4. Net Saving Rate: KA Openness, External Financing Dependence, and Export

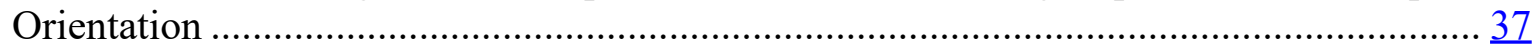

Table A5. Interaction between KA Openness and External Financing Dependence by Export Orientation ....................................................................................... 38

Table A6: Net Saving Rate: ER Flexibility, External Financing Dependence, and Export

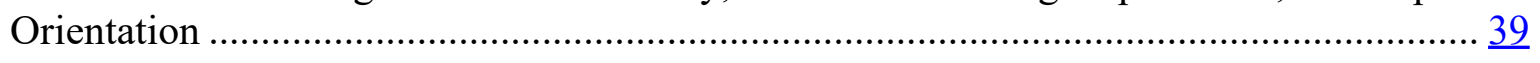

Table A7: Banking Sector Efficiency, Competitiveness, and Net Saving ...................... 40

Table A8: Political Stability and Net Saving ............................................................. 41 


\section{INTRODUCTION}

From a global perspective, the non-financial corporate sector in advanced economies has begun to shift from a net borrower to a net lender in the 2000s. However, the rise in profits did not translate into higher investments, resulting in growing cash holdings of firms. Similar patterns are observed in ASEAN5 countries. ${ }^{2}$ In the case of large profits, ASEAN5 firms have tended to increase net saving, as opposed to paying more dividends or increasing investment.

While similar, corporate saving behavior in ASEAN5 countries may have different underlying drivers than its counterpart in advanced economies. In advanced economies with deep financial markets, flexible exchange rates, and open capital accounts, the rise in corporate saving is largely driven the rise of tech firms. (Bates et al., 2009; Booth and Zhou, 2013; Begenau and Palazzo, 2017). In contrast, high-tech companies in most ASEAN5 economies are relatively young and have a much lower saving rate compared to high-tech firms in the U.S. (Figure A2). Separately, Indonesia, Malaysia, Philippines and Thailand have relatively less developed financial markets and a history of using a range of measures, including FXI and capital flow measures, to tackle external shocks. These aggregate characteristics are likely to help explain corporate saving behavior of ASEAN5 countries.

Indeed, in countries with less developed financial markets, corporates are more likely to face binding borrowing constraints. These constraints imply that firms may be unable to get enough funds or must borrow at a higher cost than the risk-adjusted rate offered in a frictionless financial market. As a result, firms may save more for precautionary motives in order to (i) reduce future transaction costs when the costs of raising external funds are high (Almeida et al., 2004) or (ii) to manage potential liquidity shortfalls when external financing is not available (Han and Qiu, 2007). ${ }^{3}$ Moreover, while large export-oriented firms' foreign earnings provide a natural hedge

\footnotetext{
${ }^{2}$ ASEAN5 countries include Indonesia, Malaysia, Philippines, Singapore, and Thailand.

${ }^{3}$ There are other motives documented in the literature, such as the misalignment between managers' and shareholders' propensity to save, which could be exacerbated by weak corporate governance (Opler et al., 1999;
}

(continued...) 
against financial shocks (thus reducing the need for precautionary saving)capital flow measures, such as surrender and repatriation requirements on exporters, play a role of "throwing sands in the wheels", which could lead to excess precautionary saving.

In addition to country-level features, corporate saving behavior could also be explained by industry- and firm-level characteristics, and such characteristics can also interact with countrylevel features to jointly determine saving behavior. One such feature that has been extensively studied in the literature of corporate finance is external financing dependence (EFD) - $\mathrm{a}$ measure of a firm's use of debt or equity issues to finance operations/investments, originally proposed by Rajan and Zingales (1998). ${ }^{4}$ Firms in some industries are more dependent on external financing than others for technological reasons. For examples, if an industry's production technology requires firms to make larger initial investment and longer investment, then firms in this industry will be unlikely to generate positive operating cash flows simultaneously to finance investment projects and thus be more reliant on external funds.

Rajan and Zingales argue that in a hypothetical frictionless financial system, a firm can raise external funds equal to the optimal amount that fully reflects the technological characteristics of the industry. In contrast, in a less developed financial system, the amount of external financing raised by a firm can partly reflect the constrained access to external funds and thus is suboptimal. It follows from the precautionary and transaction cost motives that industries with high $\mathrm{EFD}^{5}$ are expected to be more financially constrained and tend to save more in a less developed financial system. Applying the same logic to other country-specific characteristics discussed above (e.g., capital account (KA) openness and exchange rate (ER) flexibility), one would expect that the

\footnotetext{
Aoyagi and Giovanni, 2014; Sher, 2014), or the avoidance of higher tax on repatriated profits by holding excess cash balances abroad. But testing these theories are beyond the scope of this paper.

${ }^{4}$ Following Rajan and Zingales (1998), external financing dependence roughly refers to a firm's use of external finance, including borrowings and equity issues. It equals total capital expenditure less cash flows from operations. It is unrelated with the country origin of the funds. A rigorous definition will be given in Section III.

${ }^{5}$ Such as mining, refinery, construction, and machinery industries.
} 
marginal effects of these aggregate characteristics on corporate saving are also dependent on firm-specific characteristics.

This paper investigates the differential effects of country-level characteristics and policies on firm-level saving behavior, with a focus on understanding the role of industries' exportorientation and external financing dependence in driving the differential responses of firms to aggregate factors.

The main findings are as follows. In the context of ASEAN5 countries, industries with high external financing dependence grow relatively faster in countries with more developed financial systems in the past two decades; for a given ASEAN5 country, industries that are more dependent on external financing tend to save more ceteris paribus, suggesting binding financial constraints in these countries. The impacts of KA openness and ER flexibility vary across industries with different external financing dependence and export orientation. Greater KA openness or ER depreciation reduces the average saving rate of industries with low dependence on external funds but increases the saving rate of industries with high dependence. KA openingup or ER depreciation disproportionately reduces the saving of export-oriented industries, with an exception for exporters that are highly dependent on external funds. In addition, an improvement in the banking sector's competitiveness or lending efficiency lowers the average corporate saving rate. Greater political stability is associated with lower corporate saving of all firms, presumably because of greater policy clarity.

The reminder of the paper is organized as follows. Section II describes the data and shows aggregate and firm-level stylized facts. Section III discusses the construction and the use of external financing dependence. Section IV presents empirical results. Section V concludes.

\section{A. Literature Review}

From a global perspective, the non-financial corporate sector has seen important structural changes in recent decades, including a decline in labor income shares, higher market concentration, and declining investment and productivity growth (IMF, 2019a). However, rising 
profits did not translate into higher investments, resulting in growing cash holdings of firms. The non-financial corporate sector has begun to shift from a net borrower to a net lender in the 2000s. (Chen et al., 2017). This trend has been broad-based and has emerged even earlier in G7+2 countries, ${ }^{6}$ driven by increased ability of large, publicly listed firms across advanced economies to extract larger profits and expand in size over time while limiting payouts to shareholders and taxes (Dao and Maggi, 2018). Empirical evidence shows that the shift in corporate saving in these advanced economies has been driven largely by the rise of high-tech companies (Bates et al., 2009; Booth and Zhou, 2013; Begenau and Palazzo, 2017).

A rise of corporate saving has also been documented for emerging market economies, with a focus on the role of credit constraints. Indeed, a large share of empirical literature aims to shed light on China's saving puzzles. ${ }^{7}$ In addition, Fan and Kalemli-Özcan (2016) look at a larger set of emerging Asian countries and find that financial reforms helped reduce saving of previously credit constrained firms (private firms) relative to unconstrained ones (SOEs), but corporate sector saving increased after financial reforms and this increase is larger for industries that are more dependent on external finance. On the theoretical front, Bacchetta and Benhima (2015) rationalize firms' increased saving, by showing the complementarity between the demand for liquid foreign bonds and domestic investment in fast growing emerging markets faced by liquidity constraints.

Conventional wisdom suggests that exchange rate affects corporate saving through two opposing channels. On one hand, ER depreciation reduces exporters' saving by improving their competitiveness and boosting investment. On the other hand, depreciation weakens the balance sheet of firms with foreign currency-denominated liabilities and reduces their access to external finance, incentivizing higher internal saving for precautionary purposes. Recent research finds

\footnotetext{
${ }^{6}$ G7+2 countries comprise US, UK, Canada, France, Germany, Italy, Japan, Korea, the Netherlands.

${ }^{7}$ For instance, Kuijs (2006) attributes the increase in national saving in China to the rise in corporate and government saving rather than to the increase in household saving; whereas Bayoumi, Tong, and Wei (2012) find that Chinese firms do not have a significantly higher savings rate than the global average and the rising corporate savings rate is also consistent with a global trend.
}

CInternational Monetary Fund. Not for Redistribution 
that the competitiveness channel is less effective for countries/regions that are (i) invoicing in a dominant currency (Casas et al., 2016; IMF, 2019b) or (ii) heavily integrated into the global supply chain (Amiti et al., 2014). ASEAN5 countries nowadays meet both features.

\section{DAta AND STYLIZED FACTS}

This section will first elaborate on key aggregate stylized facts in ASEAN5 and then present firm-level analysis of the drivers of corporate saving from an accounting perspective.

\section{A. Aggregate Stylized Facts}

ASEAN5 countries are deeply integrated into global value chains (GVCs), with manufacturing industries heavily oriented towards foreign markets. According to the TiVA database, ${ }^{8}$ more than half of the manufacturing industries in ASEAN5 have export-orientation rates over 50 percent, with Electrical and Electronic Products, Basic Metals, Machinery and Equipment, and Chemical and Pharmaceutical Products topping the list. ${ }^{9}$ (Figure A3.1) Among ASEAN5 countries, Malaysia and Singapore have the highest manufacturing export-orientation rates, followed by Thailand. Export orientation rates have decreased slightly over the TiVA sample period (2005-2015) across almost all countries and all industries, partly reflecting the increasing size of domestic markets. (Figure A3.2)

Indonesia, Malaysia, Thailand, and Philippines (ASEAN4) have capital flow measures in place. ${ }^{10}$ Figure A4.1 compares the average capital account (KA) openness in ASEAN4 with different country groups, based on the Chinn-Ito Index. The overall KA openness of ASEAN4

\footnotetext{
${ }^{8}$ According to the OCED's TiVA methodology, export orientation is defined as the value-added originating from an industry of a country that is embodied (via exporting activities) in foreign final demand — as a share of the total domestic value added generated by that industry.

${ }^{9}$ ASEAN5 countries' high export-orientation rates also reflect their relatively small economic size. Larger countries, including those that are highly integrated within GVCs, often have rates significantly lower than smaller countries, partly reflecting the size of the domestic market being served by domestic industries.

${ }^{10}$ Singapore is excluded from the discussion on capital account openness in this paragraph, as it is the only advanced economy and financial center in ASEAN5 countries.
} 
countries has been significantly lower than advanced economies (AEs), as well as emerging Europe and LACs, throughout the entire sample period. While ASEAN4 countries had more open capital accounts relative to other emerging Asia countries prior to the global financial crisis (GFC), there was a temporary reversal in the wake of the GFC as some ASEAN4 countries introduced new measures to contain capital account transactions (Figure A4.2) and began to catch up with their Asian peers in recent years.

ASEAN4 countries' financial markets are less developed relative to markets in advanced economies, but they are more developed on average than markets in the rest of emerging Asia, emerging Europe, and LACs. Figure A6 shows the evidence drawn from the Global Financial Development Database ${ }^{11}$, including the metrics for depth (Figure A6.1 and A6.3), efficiency (Figure A6.4), stability (Figure A6.5), and concentration (Figure A6.6) of financial systems. There are heterogeneities within ASEAN5 countries as well. Taking the depth of the financial system as an example, total credit to the private sector in Thailand or Malaysia exceeds 110 percent of GDP, which is above the average level in advanced economies; whereas credit-toGDP ratios are below 50 percent in Indonesia or the Philippines (Figure A6.2).

\section{B. Firm Level Analysis}

We employ balance sheet and income statement data for a total of 3503 publicly listed firms over the period 2000-2017, drawing from the Thompson WorldScope Database. ${ }^{12} 2530$ firms are listed as of end-2017, with total assets accounting for 75 percent of ASEAN5 GDP (see Table A1). As the interpretation of cash and investment flows for financial corporations is different from that for non-financial corporations, we focus on the financing decisions of non-financial corporations only (see Fama and French, 2001; and DeAngelo et al., 2004). All variables are winsorized at 1 percent to remove possible effect of outliers. A drawback of the WorldScope

\footnotetext{
${ }^{11}$ The Global Financial Development Database is an extensive dataset, maintained by the World Bank, of financial system characteristics for 214 economies since 1960 .

12 Worldscope utilizes consolidated account data when it is disclosed.
}

(continued...) 
database is that it does not include information on non-listed firms, which might have different motives for saving from listed firms. Key variables of interest are defined as follows. ${ }^{13}$

$$
\begin{gathered}
\text { Profit }=\text { Gross Operating Surplus }- \text { Taxes on Profits - Interest; } \\
\text { Gross Saving }=\text { Profit }- \text { Net Dividends; } \\
\text { Net Saving }=\text { Gross Saving - CapEx. }
\end{gathered}
$$

Both gross and net saving rates of non-financial firms in ASEAN5 exhibit cyclical fluctuations during the sample period in 2000-2017 (Figure A1). The upward trend of corporate saving rates ceased in 2008 as the average firm profit was halved during the GFC, leading to a sudden dip in both gross and net corporate saving rates. After a quick recovery around 2009 and 2010 , both rates began to decline since 2011 for 5 years. Although these rates picked up across the board since 2015, it is too early to judge whether the recent upswing reflects another cyclical movement or a trend. Overall, gross and net saving rates have cumulatively increased by 1.8 and 1.9 percentage points, respectively, since 2000.

Following Chen et al. (2017), firms are divided into groups $i=1,2, \ldots, I$ by quartiles of size or age, and then employ a standard decomposition method to quantify the contributions of the within- and between-group components to the cumulative changes in the corporate saving rate from 2000 to 2017. Specifically, the changes in the aggregate saving rates from period $t-1$ to $t$ can be decomposed as follows:

$$
\Delta s_{t}=\frac{1}{2} \sum_{i}\left(\omega_{i, t}+\omega_{i, t-1}\right) \Delta s_{i, t}+\frac{1}{2} \sum_{i}\left(s_{i, t}+s_{i, t-1}\right) \Delta \omega_{i, t},
$$

where $\Delta s_{i, t}=s_{i, t}-s_{i, t-1}$ is the change in the gross (or net) saving rate of group $i$ in period $t$ and $\omega_{i, t}$ denotes the share of group $i$ in total asset in period $t$. The first component in the above equation is the within-group effect; whereas the second component the between-group effect. As is shown in Table 1, the cumulative changes in the aggregate gross saving rate is entirely driven by the within-age group component. While part of the changes in the aggregate gross saving rate is due to the between-size group component, most of the changes is accounted for by changes in the within-size group component. In other words, the change in the aggregate saving rate is not mainly driven by the change in the share of old firms or large firms, relative to 2000; instead, it

\footnotetext{
${ }^{13}$ These variables are defined as shares of total asset, as opposed to profit or gross value added (GVA), because data limitation prevents an accurate calculation of GVA at the firm level.
} 
reflects that firms of similar age or size are behaving differently today compared to 2000, Similar trends are found in the changes in the net saving rate.

Table 1. ASEAN5: Within-between Decomposition of Changes in Saving Rate

(2000-2017, percent contribution)

\begin{tabular}{cccccc}
\hline & \multicolumn{2}{c}{ gross savings } & & \multicolumn{2}{c}{ net savings } \\
\cline { 2 - 3 } \cline { 5 - 6 } & within & between & & within & between \\
\hline age & 102.7 & -2.7 & & 117.4 & -17.4 \\
size & 92.9 & 7.1 & & 94.9 & 5.1 \\
\hline
\end{tabular}

Notes: The table presents results from the within-between decomposition

for groups of firms $i$ defined by quartiles of age and quartiles of size.

Firm-level data confirms that in case of large profits, non-financial firms in ASEAN5 tend to increase their net saving, as opposed to paying more dividends or increasing investment. The four panels of Figure A7 plot the 10-year trend in firm profit against the trends in its main components. The area of each circle corresponds to a firm's average size over the sample period. The top panels show a strong cross-sectional relationship between trends in the gross saving rate and trends in profit relative to total assets, partly because of a weak correlation between profit and dividends. The bottom panels show that trends in investment are uncorrelated with trends in profit, leading to a meaningful positive relationship between profit and the net saving rate. These conclusions are robust if the 10 -year trend is replaced with a 5-year trend.

\section{EXTERNAL FinanCING DEPENDENCE}

Industries have different dependence on external funds, contingent on the technological characteristics of the industry. We define the external financing dependence (EFD) at the industrial level following a two-step process developed by Rajan and Zingales (1998). First, we derive a firm's EFD by summing the firm's use of external finance (borrowings and equity issues, which equals total capital expenditure less cash flows from operations) over a 10-year period and then divide it by the sum of capital expenditure over the same period, i.e., (CapEx Opt. CashFlow)/CapEx. ${ }^{14}$ Then, to summarize the EFD across all firms in an industry, we use the industry median. ${ }^{15}$

\footnotetext{
14 The sum of cash flows over a period of 10 years could be a good approximation of cumulative cash stock, unless the firm had a large initial cash stock in the beginning of the period (e.g., mature firms).

${ }^{15}$ Similar to Rajan and Zingales (1998), we treat large and small firms equally, which allows us to prevent large, mature firms from swamping the information of small firms (e.g., Apple's large free cash flow should not mask the possible constraint faced by smaller IT firms).
}

(continued...) 
While an industry's actual dependence on external financing may differ significantly across countries, its desired dependence on external funds is identified using the data on firms in the United States and applied to other countries. This approach is reasonable because: (i) the production functions ${ }^{16}$ of the same industry are similar across different countries - particularly, the same industry in the manufacturing sector is more likely to use similar technologies across different countries than the services sector does; and (ii) capital markets in the United States are relatively frictionless - as a result, the actual amount of external funds raised by a firm in the United States reflects the technological demand for financing, as opposed to supply constraints.

The Rajan and Zingales approach has been extensively used in the literature of corporate finance. However, 20 years have passed since the publication of Rajan and Zingales' original paper and the EFDs of U.S. industries may have changed significantly since then for two reasons. First, incumbent firms have become more mature over the past three decades and as indicated in the previous section, mature firms save more and are thus less reliant on external funds. Second, breaking-through innovations could have fundamentally changed the production function of manufacturing and services sectors and hence the EFD of firms operating in these sectors. While it is beyond the scope of this paper to explore the impact of new technologies on firms' reliance on external funds, we revisited the evolution of the EFD across U.S. industries/firms in order to make an informed choice of the desired EFD for firms in ASEAN5.

A few useful observations can be drawn from this exercise. First, young firms tend to depend more on external funds, as is shown by the declining median EFD of firms in the United States in Figure A8. Second, Figure A9 reveals that the distribution of EFD is generally shifting downward over time for firms listed on both NASDAQ and NYSE. Third, firms listed on NASDAQ have larger EFD than those listed on NYSE, as NASDAQ has a larger share of young and small firms than NYSE. Last, additional figures in Appendix I further show that industries' relative rankings in different decades are relatively stable except for a few industries with larger EFD in 2010s relative to 2000s (Figure A11). Indeed, what really matters in the empirical analysis below is the EFD ranking. The magnitude of EFD is of second order. Based on these observations, the desired EFD for ASEAN5 are benchmarked, industry-by-industry, to the actual EFD of U.S. firms listed on NASDAQ in 1990s.

At the industry level, Figure A10 compares firms' actual EFD in ASEAN5 countries (y-axis) with their desired EFD proxied by the actual EFD of their counterparts in the United States ( $x$ -

\footnotetext{
${ }^{16}$ Production function is used to represent the investment cycle of an industry driven by the technological characteristics associated with the industry, such as size of initial investment, implementation period, cash harvest period, and follow-up investment.
} 
axis). The size of the circle represents the average size of the associated industry in a ASEAN5 country over the sample period. While the EFD of a certain industry varies across ASEAN5 countries, there is a statistically positive relationship between the actual and desired EFD level of firms. There is a larger number of industries in ASEAN5 countries that rely more on internal funds (savings) to finance their investments than their counterparts did in the USA (i.e., below the 45-degree line in Figure A10). This fact could imply either that ASEAN5 firms are financially constrained or that they do not require as much external financing as their counterparts in USA did two decades ago. Section IV below will address this question by empirically testing the hypothesis that industries that are more dependent on external financing will have higher growth rates in countries that have more developed financial systems.

\section{EMPIRICAL ANALYSIS}

\section{A. Models}

The main purpose of this paper is to study corporate saving behavior in ASEAN5 countries through the lens of external financing dependence. Since the EFD would affect corporate saving only when firms are facing borrowing constraints, in the first place it is imperative to test whether ASEAN5 firms are financially constrained or not. We address this issue indirectly.

Following Rajan and Zingales (1998), we test the hypothesis that industries that are more dependent on external financing will have higher growth rates in countries that have more developed financial systems. The dependent variable is the annual growth rate of firms. Financial development indicators, $m_{k}$, are drawn from the Global Financial Development Database and measure the depth, efficiency, stability, and competitiveness of financial systems. It is worth noting that "financially constrained" means either that firms are not able to borrow adequate resources in the financial market or that firms must borrow at a higher cost than the risk-adjusted rate offered by a frictionless market. Therefore, both the depth and efficiency of financial markets matter.

After controlling for country and industry effects, the paper tests whether the coefficient for the interaction between EFD and financial development in the following equation is positive.

$$
g_{i j k t}=\alpha+\alpha_{t}+\alpha_{i}+\rho_{1} g_{i j k t-1}+\rho_{2} g_{i j k t-2}+X_{i t}^{\prime} \beta+Y_{j t}^{\prime} \gamma+\left(F_{j} \cdot m_{k t}^{\prime}\right) \delta_{1}+\varepsilon_{i j k t},
$$

where $g_{i j k t}$ is the growth rate of firm $i$ in industry $j$ in country $k$ at time $t ;{ }^{17} X_{i t}$ and $Y_{j t}$ are arrays of firm-level and industry-level characteristics, respectively; and $F_{j} \cdot m_{k t}$ is the interaction

\footnotetext{
${ }^{17}$ Firm growth rate is defined as the percent change in firm's total asset per annum.
} 
between the industry j's desired EFD and a country's financial development. The unobserved panel-level effects are correlated with the lagged dependent variables, making standard estimators inconsistent. Arellano and Bond's (1991) GMM technique for dynamic panels with lagged dependent variables is employed to get a consistent estimator for the parameters.

Second, we focus empirical tests on the drivers of corporate net saving and their interactions with external financing dependence. A firm's saving behavior can be attributed to the following motives: (i) reducing future transaction costs when the costs of raising external funds are high (Almeida et al., 2004); (ii) the precautionary demand for cash to manage a potential liquidity shortfall when external financing is not available (Han and Qiu, 2007); (iii) the misalignment between managers' and shareholders' propensity to save, which could be exacerbated by weak corporate governance (Opler et al., 1999; Aoyagi and Giovanni, 2014; Sher, 2014); and (iv) avoiding higher tax on repatriated profits by holding excess cash balances abroad.

Against these theoretical backdrops, we focus on the differential effects of KA openness and ER flexibility on exporters and non-exporters and on firms with different external financing dependence. We also look at the impact of banking sector efficiency and political stability (as a proxy for economic policy uncertainty) on corporate saving.

To test the above theories, we estimate the following equation using Arellano and Bond's (1991) GMM technique:

$$
s_{i j k t}=\alpha+\rho_{1} s_{i j k t-1}+\rho_{2} s_{i j k t-2}+X_{i t}^{\prime} \beta+Y_{j t}^{\prime} \gamma+P_{k t}^{\prime} \delta_{1}+\left(F_{j} \cdot P_{k t}^{\prime}\right) \delta_{2}+\varepsilon_{i j k t},
$$

where $s_{i j k t}$ is the net saving rate of company $i$ in industry $j$ in country $k$ at time $t . X_{i t}$ and $Y_{j t}$ are arrays of firm-level and industry-level characteristics, $P_{k t}$ represents a set of macro-financial and structural factors in country $k . F_{j} \cdot P_{k t}^{\prime}$ is the interaction of industry $j$ 's desired EFD with macrofinancial and structural factors. ${ }^{18}$ The industry-specific vector, $Y_{j t}$, includes the industry $j$ 's average profit as a share of total asset in period $t$ and its square term. More specifically, the firmspecific vector, $X_{i t}$, includes the natural logarithm of total assets, the quartile of firm age since incorporation, and Tobin's Q measured by the ratio of the sum of market capitalization and total debt to total assets. ${ }^{19}$ Policy variables of interest comprise capital account (KA) openness,

\footnotetext{
${ }^{18} F_{j}$ cannot be added to the regression because of the multicollinearity between $F_{j}$ and the firm level dummies $\left\{\alpha_{i}\right\}_{i \in j}$.

${ }^{19}$ The presence of large conglomerates, a characteristic feature of the ASEAN corporate sector, may also affect corporate saving. With other things equal, a subsidiary company that has access to intra-group financing sources would have a lower tendency to save. Nevertheless, this firm-specific variable is not included in the regressions as the WorldScope uses consolidated account data.
}

(continued...) 
exchange rate (ER) flexibility, banking sector efficiency and competitiveness, as well as political stability. ${ }^{20}$

\section{B. Results}

\section{Are corporates in ASEAN5 facing binding borrowing constraints?}

Estimation results of equation (1) are reported in Table A2 in Appendix II. Various measures of financial development are employed, including the domestic credit-to-GDP ratio, total capitalization (in percent of GDP), bank interest rate spread, bank NPL rate, and bank concentration..$^{21}$ Columns (1) to (5) in Table 1 show the results of the baseline specification with only one proxy for financial development included at a time.

Except for total capitalization, the estimated coefficients of the interaction term are uniformly significant at the 5-percent level, with their signs in line with the hypothesis that financial development tends to facilitate the growth of external financing dependent industries. This suggests that corporates in ASEAN5 countries may be facing financial constraints during the sample period 2000-2017. For instance, the industries at the $25^{\text {th }}$ and $75^{\text {th }}$ percentile of dependence (among all manufacturing industries in ASEAN5) are Rubber and Plastic Products and Oil and Gas Extraction, respectively. The estimated coefficient in column (1) suggests that with other factors fixed, one percentage point increase in the credit-to-GDP ratio is associated with the Oil and Gas Extraction industry (high dependence on external funds) growing 0.3 ppts per year faster than the Rubber and Plastic Products industry (low dependence). Similarly, column (3) suggests that the Oil and Gas Extraction industry should grow 1.3 percentage points per year faster than Rubber and Plastic Products if the interest rate spread is reduced by 1 percentage point.

\section{What factors are driving the net corporate saving rate in ASEAN5?}

Estimation results of equation (2) are presented in Table A3-A8 in Appendix II. Table A3 shows the effect of EFD, as well as other industry- and firm-specific factors, on the corporate net saving

\footnotetext{
${ }^{20} \mathrm{KA}$ openness is based on the Chinn-Ito Index which has been updated to 2016. ER flexibility is measured by the depreciation of local currency in percent in the previous period. Bank sector efficiency and competitiveness indicators are drawn from the Global Financial Development Database and will be discussed in detail later. Political stability is drawn from the International Country Risk Guide (ICRG) database.

${ }^{21}$ Bank concentration is measured by assets of three largest commercial banks as a share of total commercial banking assets.
} 
rate. For both industry- and firm-specific variables, signs of the statistically significant coefficients support the transaction cost and precautionary saving theories and the role of external financing dependence.

- External financing dependence: Since the multicollinearity between $F_{j}$ and firm fixed dummies prevents us from testing the effect of $F_{j}$, we interact $F_{j}$ with Tobin's Q. The positive relationship between the net saving rate and external financing dependence (interacted with Tobin's Q) shows that in a financially constrained environment, firms with higher dependence on external finance tend to save more. This is particularly true if firms see more future investment opportunities (a higher Tobin's Q) — consistent with the transaction cost or precautionary demand theory.

- Tobin's $Q$ : The negative relationship between the net saving rate and Tobin's Q seems inconsistent with either theory of transaction cost or precautionary demand - as it implies that firms with more future investment opportunities do not want to save more in the current period to hedge against possible liquidity shortfalls in the future. Nevertheless, after interacting Tobin's Q with the desired external financing dependence, the coefficient on the interaction term turns positive. That is, promising firms in industries with larger EFD have an incentive to save more, consistent with both the transaction cost and precautionary saving motives.

- Firm size and age: after controlling for lagged terms, the positive relationship between the net saving rate and firm size is in line with the findings in other papers that industrial concentration and rising market power of large firms have led to a rise in corporate profits and thus an increase in corporate saving (IMF, 2019a). The coefficient on firm age quartile is negative after controlling for firm size, consistent with our finding in the previous section that young firms are more dependent on external funds than mature firms.

- Average profit at the industry level: the positive coefficient on industry-specific average profit reflects the propensity of firms to save part of their operating cash flow, driven by either the transaction cost or precautionary demand motives. The negative coefficient on the square of industry-specific average profit means that firms in more profitable industries tend to invest a larger share of cash flow and save less.

The effects of macro policies and financial development (differentiated by EFD) are reported in Table A4-A6.

- Interaction between KA openness and external financing dependence: specification (1) in Table A4 repeats the baseline regression in Table A3 on firm- and industry-specific characteristics. After controlling for these variables, specifications (2)-(4) show the 
asymmetric effect of KA openness on corporate net saving. While greater KA openness reduces the net saving rate of firms in industries with low demand for external funds, firms with high external financing dependence tend to save more. This is because a more open KA increases the availability of funds for firms in good time, reducing the incentive of a firm to save on average. But it also leads to vulnerability to capital outflows in bad times when external financing may be unavailable or costlier. According to the precautionary saving and transaction cost theory, industries with higher EFD tend to save more in good time.

- Interaction between KA openness and export-orientation: as discussed in Section I, the impact of KA openness on the net saving rate also depends on the extent of export orientation of an industry. Specification (5) in Table A4 includes the interaction term between KA openness and export-orientation rate. The negative coefficients on KA openness and the interaction term indicate that a more open KA disproportionately reduces the precautionary saving of export-oriented industries, which is consistent with the argument that capital flows help finance investment and allow an efficient allocation of resources. This also implies that if a country begins to tighten controls over capital flows, exporters would respond by saving more relative to domestic oriented industries.

- Interaction between KA Openness and External Financing Dependence by Export Orientation: as is shown above, while KA openness helps lift financing constraints and reduce net saving particularly of exporters, it also incentivizes industries highly dependent on external funds to save more. It raises an interesting question - what is the net effect of KA openness on exporters in high EFD industries? Using quantile regressions, we find in Table A5 that for firms in industries with export orientation rate below 60 percent, greater KA openness does not have a negative impact on saving rates (column (2)-(5)). However, among highly export-oriented industries (export orientation rate over 60 percent), firms that are more dependent on external funds tend to save more as KA becomes more open (column (6)(9)). This could possibly be explained by the different sources of external funds accessible to domestic- and export-oriented firms - while firms that are more domestic-oriented are expected to get external funds from domestic sources, firms that are more export-oriented are more likely to have access to cross-border capital and thus more vulnerable to capital flow volatility.

- Interaction between ER flexibility and external financing dependence: Table A6 reveals the asymmetric effect of ER flexibility on the net saving rate. Specifications (2)-(4) show that for industries with lower dependence on external funds, ER depreciation helps reduce the net saving rate. But for industries with EFD breaching a threshold, depreciation increases the net saving rate. Consistent with Jiang and Sedik (2019), this result implies that the competitiveness channel of the exchange rate will eventually be more than offset by the 
negative balance sheet effect as firms' dependence on external funds increases. Specification (5) shows that export-oriented firms reduce their saving more than non-exporters in response to exchange rate depreciation because of natural hedging.

- Banking Sector Efficiency, Competitiveness: In Table A7, we test the relationship between the banking sector competitiveness and corporate saving. Banking sector competitiveness is measured by a range of indicators, including the spread between lending and deposit rates, the $\mathrm{H}$-statistics, the Lerner index, the Boone indicator, and the concentration of the largest three banks. Not surprisingly, an increase in the banking sector competition or an improvement in banks' lending efficiency lowers the corporate saving rate on average.

- Policy Uncertainty: In Table A8, we study the relationship between aggregate policy uncertainty and corporate saving. To measure policy uncertainty, the corporate saving literature often uses the economy policy uncertainty (EPU) index developed by Baker et al. (2016). However, the EPU does not cover ASEAN countries. Alternatively, we use the political instability index from the ICRG database as a proxy for economic policy uncertainty, based on the rationale that political instability can be translated into economic policy uncertainty. The results reveal that an improvement in political stability reduces corporate saving, which is consistent with the precautionary motive. In addition, the effect of political stability does not discriminate against firms with high external financing dependence.

\section{Conclusion}

From a global perspective, it has been well-documented that the non-financial corporate sector has shifted from a net borrower to a net saver over the past two decades. But the literature on corporate saving in emerging markets is relatively sparse and incomplete. ASEAN5 is a vibrant region that has been heavily integrated in the GVC and attracted substantial international capital flows. Corporate saving rates in ASEAN5 show cyclical fluctuations, as opposed to the upward trend in advanced economies. This can be partly explained by the unique features of ASEAN5 economies.

Using an extensive firm-level data set with comprehensive information on balance sheets and income statements for ASEAN5 countries, this paper studies the differential effects of macrofinancial and structural factors on corporate saving behavior. It confirms that non-financial corporations in ASEAN5 may be subject to binding financial constraints: (i) in a given period, industries with high external financing dependence grow relatively faster in countries with more developed financial systems; (ii) in a given country, industries that are more dependent on external financing, ceteris paribus, tend to save more. The impacts of KA openness and ER 
flexibility vary across industries with different external financing dependence and export orientation. Greater KA openness or ER depreciation reduces the average saving rate of industries with low dependence on external funds but increases the saving rate of industries with high dependence. KA opening-up or ER depreciation disproportionately reduces the saving rate of export-oriented industries, with an exception for exporters that are highly dependent on external funds. An improvement in the banking sector competition or banks' lending efficiency lowers the corporate saving rate on average. Greater political stability (lower policy uncertainty) is associated with lower net saving rate of all firms.

While this paper investigates the aggregate and micro drivers of actual corporate saving rates in ASEAN5, it remains a question whether the actual corporate saving rate exceeds the desired saving rate and to what extent the gap between the two saving rates contributes to a country's overall external imbalance. To address this question, a first challenge is how to conceptually define and empirically estimate the desired level of corporate saving. While this is beyond the scope of this paper, the above analysis sheds some light on a possible way forward. First of all, the desired saving rate of a firm should be a function of its external financing dependence, which is in turn determined by the production technology of its industry. Of course, one should factor in firm maturity as research show that young firms are more dependent on external funds than mature ones. In addition to the industry-level EFD, some firm-level characteristics may be also relevant, such as the export-orientation rate and firm ownership. As is shown in the paper, these firm- and industry-level fundamentals always interact with aggregate factors. Therefore, one would also need to define the desirable levels of relevant macro and financial factors/policies, such as the desirable levels of financial development, KA openness, ER flexibility etc. Further research along these lines would be needed to deepen the understanding around external imbalances, given the importance of the self-financing behavior of credit-constrained firms in rapidly growing emerging markets. 


\section{REFERENCES}

Almeida, H., Campello, M., \& Weisbach, M. S. (2004). The cash flow sensitivity of cash. The Journal of Finance, 59(4), 1777-1804.

Amiti, M., Itskhoki, O., \& Konings, J. (2014). Importers, exporters, and exchange rate disconnect. American Economic Review, 104(7), 1942-78.

Aoyagi, C., \& Ganelli, G. (2014). Unstash the cash!: corporate governance reform in Japan (No. 14-140). International Monetary Fund.

Arellano, M., \& Bond, S. (1991). Some tests of specification for panel data: Monte Carlo evidence and an application to employment equations. The review of economic studies, 58(2), 277-297.

Bates, T. W., Kahle, K. M., \& Stulz, R. M. (2009). Why do US firms hold so much more cash than they used to?. The journal of finance, 64(5), 1985-2021.

Bacchetta, P., \& Benhima, K. (2015). The demand for liquid assets, corporate saving, and international capital flows. Journal of the European Economic Association, 13(6), 1101-1135.

Bayoumi, T., Tong, H., \& Wei, S. J. (2012). The Chinese corporate savings puzzle: a firm-level cross-country perspective. In Capitalizing China (pp. 283-308). University of Chicago Press.

Begenau, J., \& Palazzo, B. (2017). Firm selection and corporate cash holdings (No. w23249). National Bureau of Economic Research.

Booth, L. D., \& Zhou, J. (2013). Increase in cash holdings: Pervasive or sectorspecific?. Frontiers in Finance and Economics, 10(2), 31-62.

Chen, P., Karabarbounis, L., \& Neiman, B. (2017). The global rise of corporate saving. Journal of Monetary Economics, 89, 1-19.

Dao, M.C., \& Maggi, C. (2018). The rise in corporate saving and cash holding in advanced economies: aggregate and firm level trends (No. 18-262). International Monetary Fund.

DeAngelo, H., DeAngelo, L., \& Skinner, D. J. (2004). Are dividends disappearing? Dividend concentration and the consolidation of earnings. Journal of financial economics, 72(3), 425-456.

Fama, E. F., \& French, K. R. (2001). Disappearing dividends: changing firm characteristics or lower propensity to pay?. Journal of Financial economics, 60(1), 3-43.

Fan, J., \& Kalemli-Özcan, Ş. (2016). Emergence of Asia: Reforms, corporate savings, and global imbalances. IMF Economic Review, 64(2), 239-267.

Casas, C., Díez, F. J., Gopinath, G., \& Gourinchas, P. O. (2016). Dominant currency paradigm (No. w22943). National Bureau of Economic Research.

Han, S., \& Qiu, J. (2007). Corporate precautionary cash holdings. Journal of Corporate Finance, 13(1), 43-57.

Horioka, C. Y., \& Terada-Hagiwara, A. (2013). Corporate cash holding in Asia (No. w19688). National Bureau of Economic Research.

International Monetary Fund. (2019a). World Economic Outlook, April 2019: Chapter 2: The Rise of Corporate Market Power and Its Macroeconomic Effects. International Monetary Fund. 
International Monetary Fund. (2019b). External Sector Report, July 2019: Chapter 2: Exchange Rates and External Adjustment. International Monetary Fund.

Jiang, B., \& Sedik, T. S. (2019). The Turning Tide: How Vulnerable are Asian Corporates?. International Monetary Fund.

Kuijs, L. (2006). How will China's saving-investment balance evolve?. The World Bank.

Opler, T., Pinkowitz, L., Stulz, R., \& Williamson, R. (1999). The determinants and implications of corporate cash holdings. Journal of financial economics, 52(1), 3-46.

Rajan, R. G., \& Zingales, L. (1996). Financial dependence and growth (No. w5758). National bureau of economic research.

Sher, G. (2014). Cashing in for growth: Corporate cash holdings as an opportunity for investment in Japan (No. 14-221). International Monetary Fund. 
APPENDIX I. FigURES

Figure A1. Corporate Saving in ASEAN5, 2000-2017

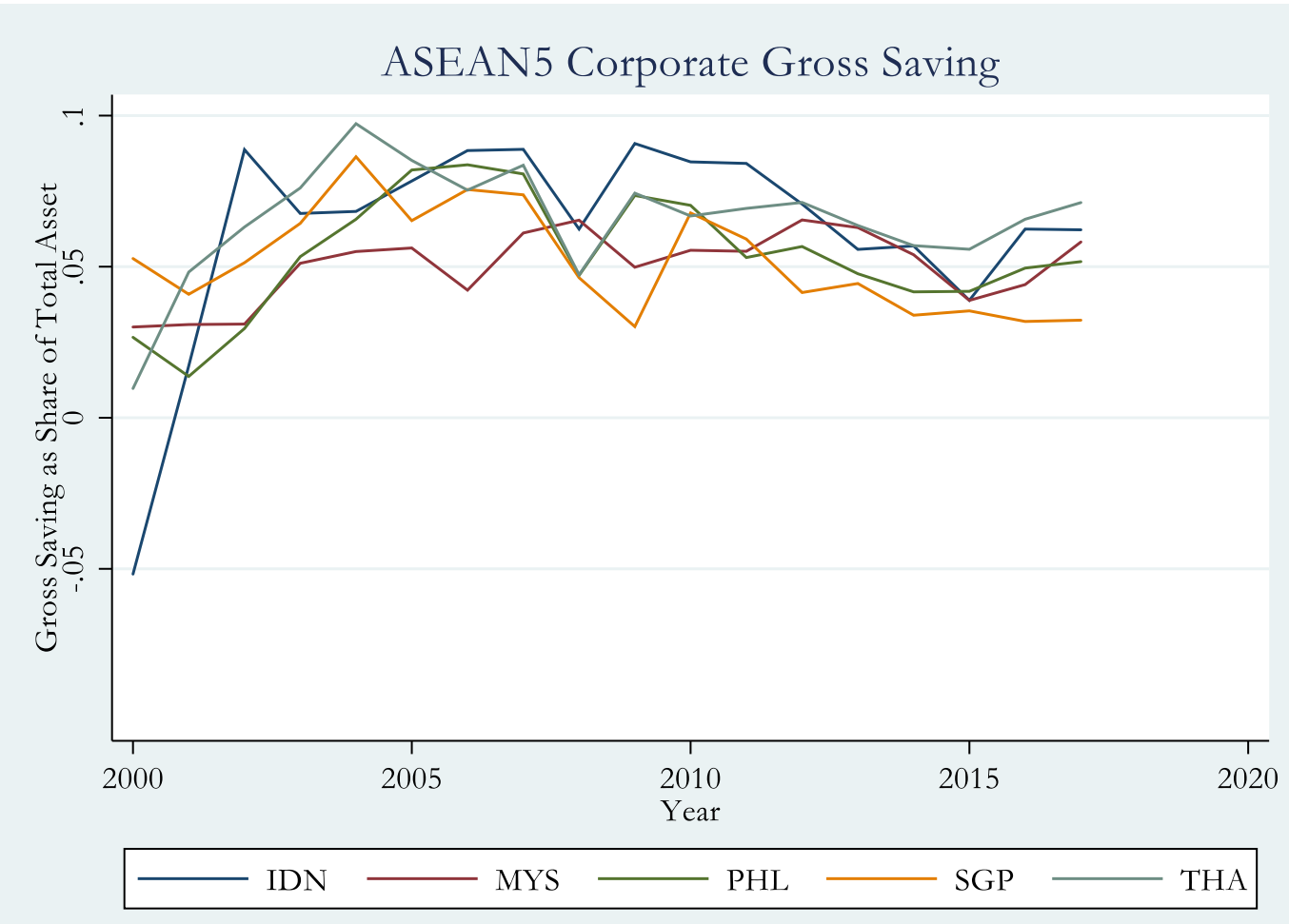

ASEAN5 Corporate Net Saving

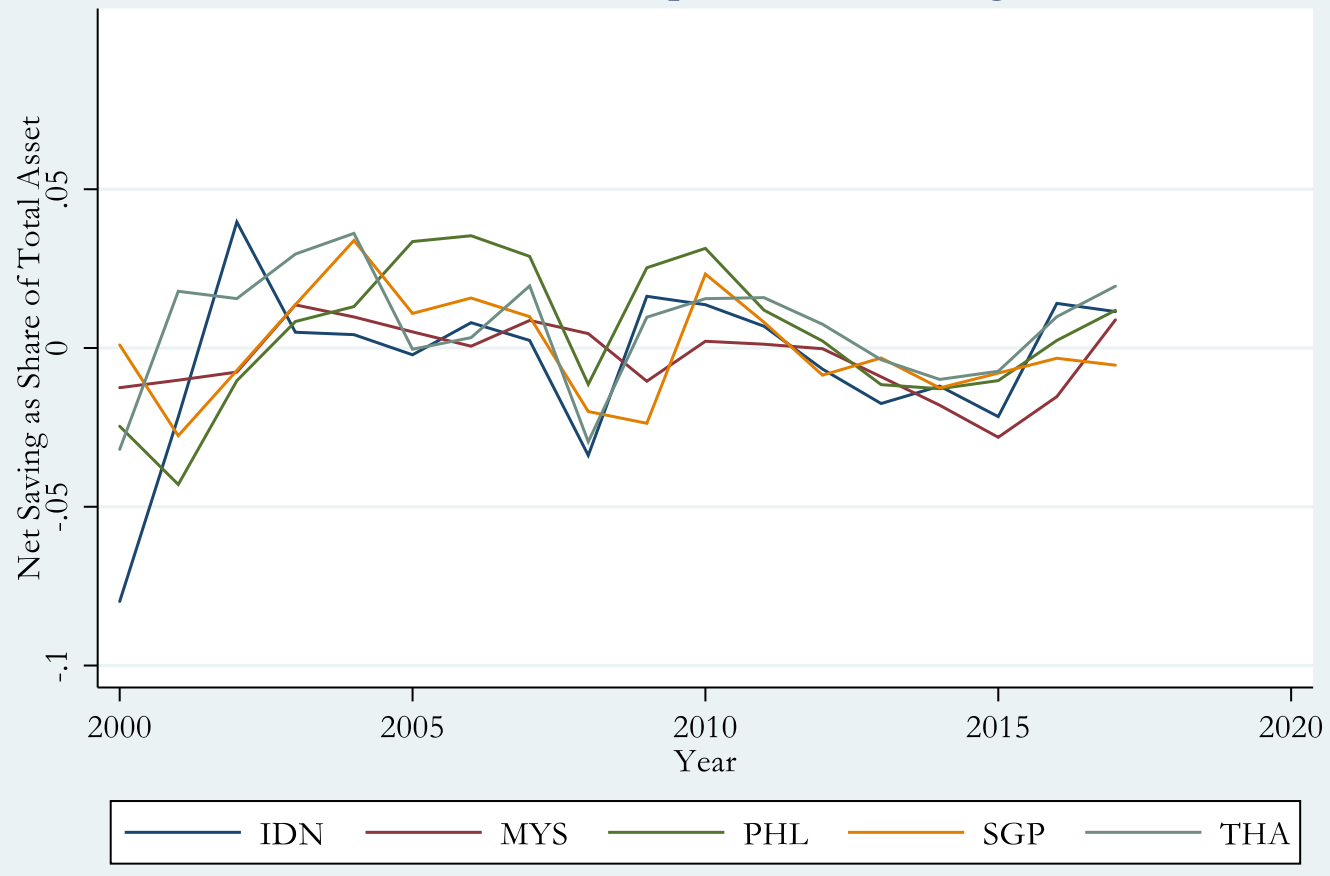

Sources: WorldScope and IMF staff calculation. 


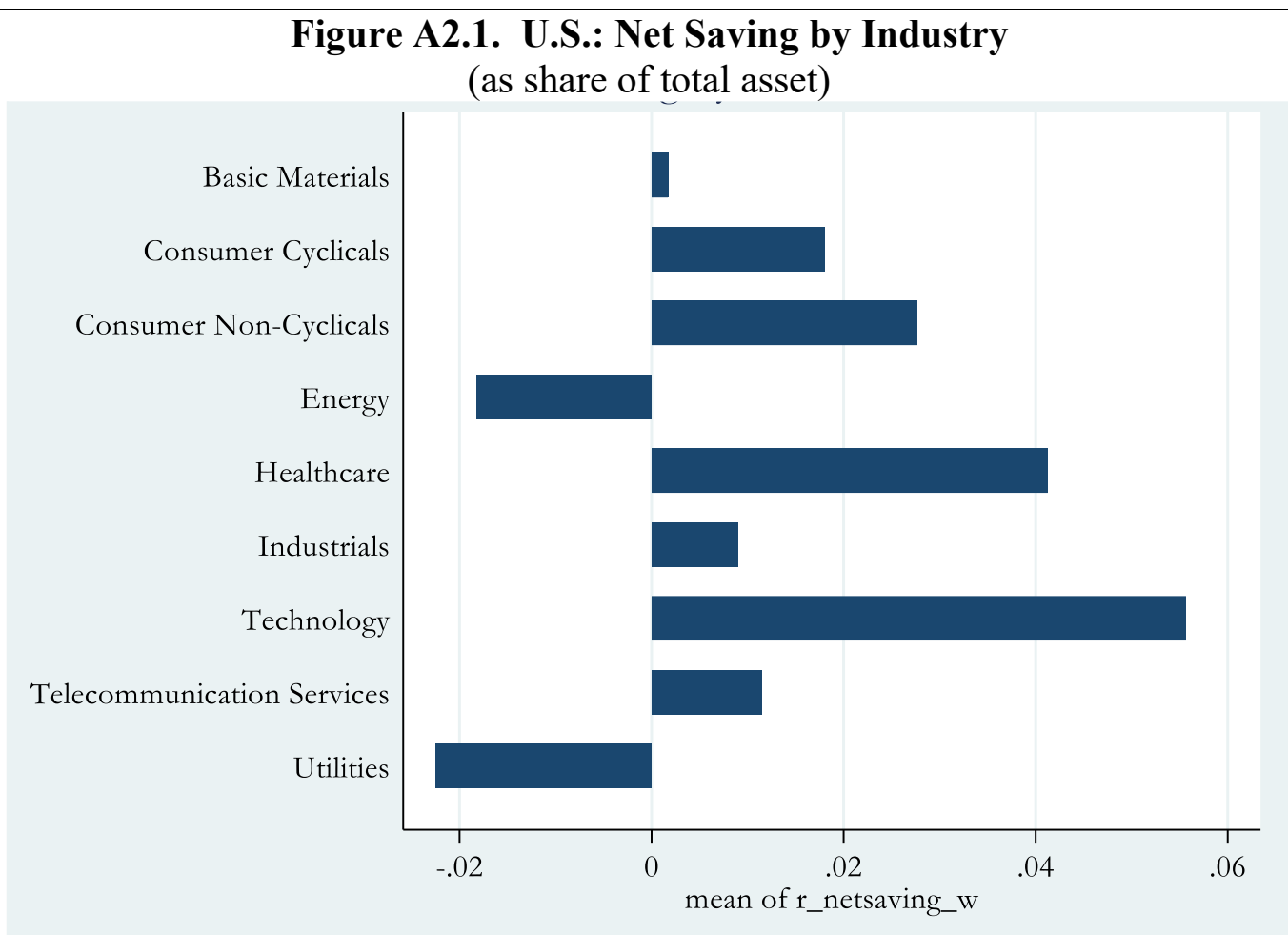

Figure A2.2. ASEAN5: Net Saving by Industry (as share of total asset)

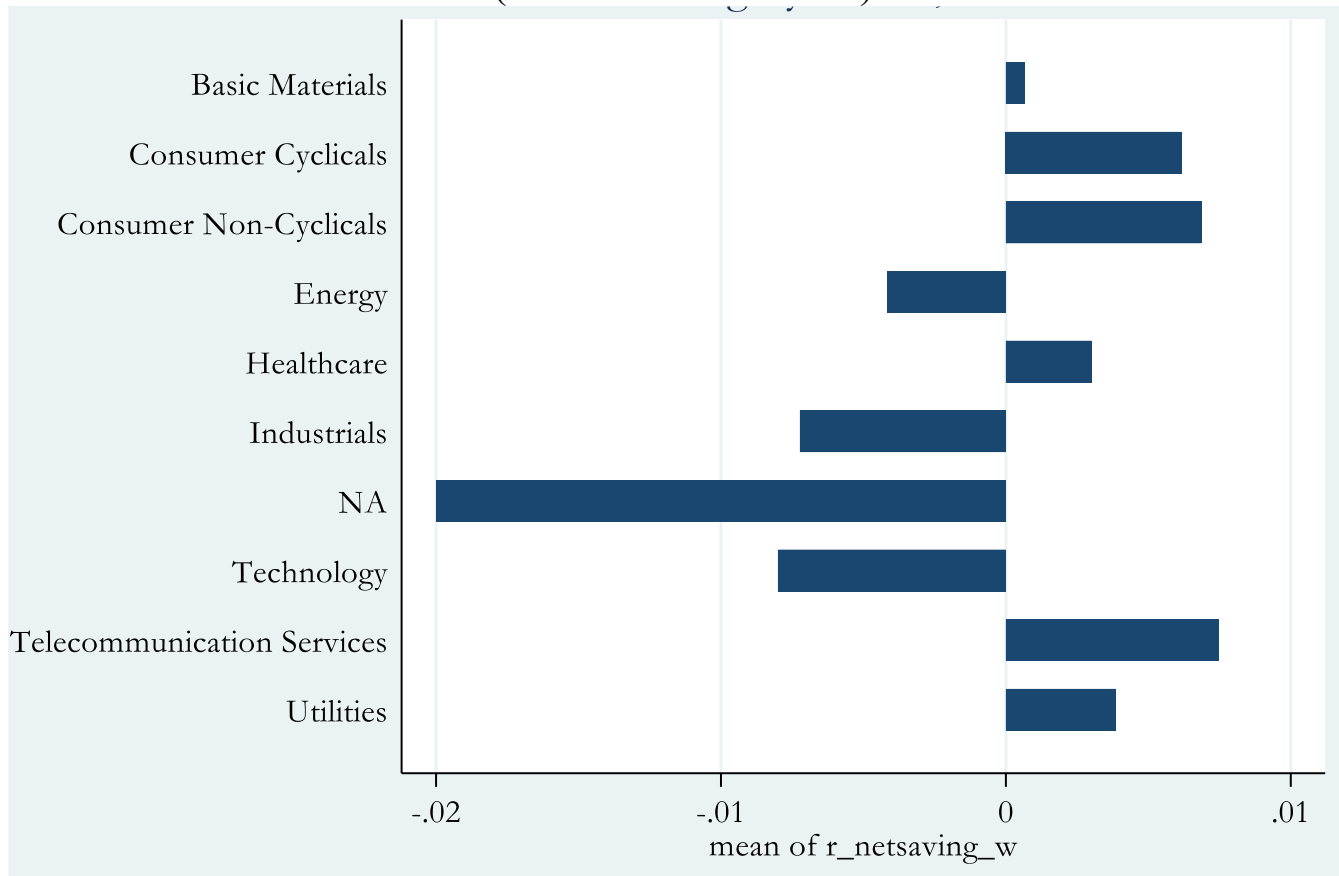

Sources: WorldScope and IMF staff calculation. 
Figure A3.1. Export-Orientation of Manufacturing Industries in ASEAN5, 2006-2016 (unweighted average)

Basic metals

Chemicals and pharmaceutical products

Coke and refined petroleum products smputer, electronic and optical products

Electrical equipment

Fabricated metal products

Machinery and equipment, nec

Motor vehicles, trailers and semi-trailers

Other Manufacturing

Other non-metallic mineral products

Other transport equipment

Paper products and printing

Rubber and plastic products ¿xtiles, wearing apparel, leather products

Wood and products of wood and cork

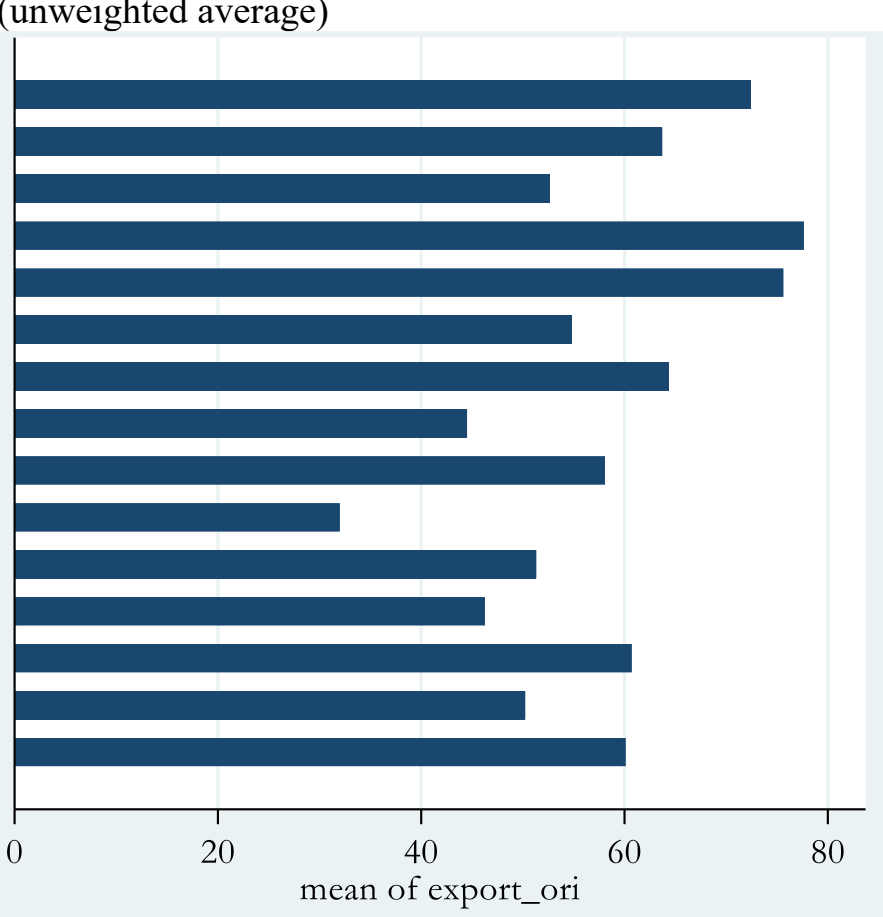

Figure A3.2. Export-Orientation of the Manufacturing Sector by Country, 2006-2016

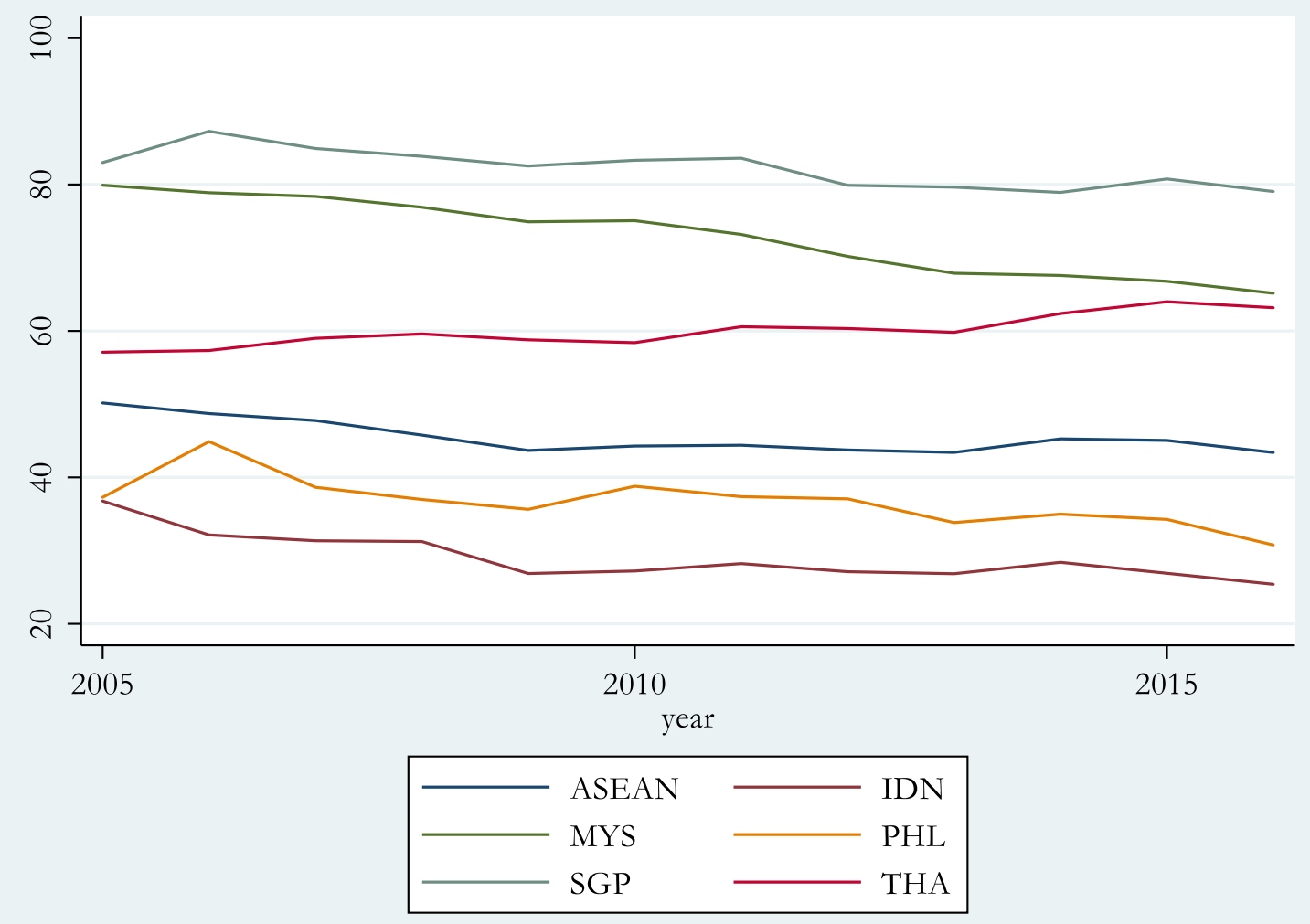

Sources: WorldScope and IMF staff calculation. 
Figure A4.1. Capital Account Openness, 2000-2017

(normalized Chinn-Ito Index by country group)

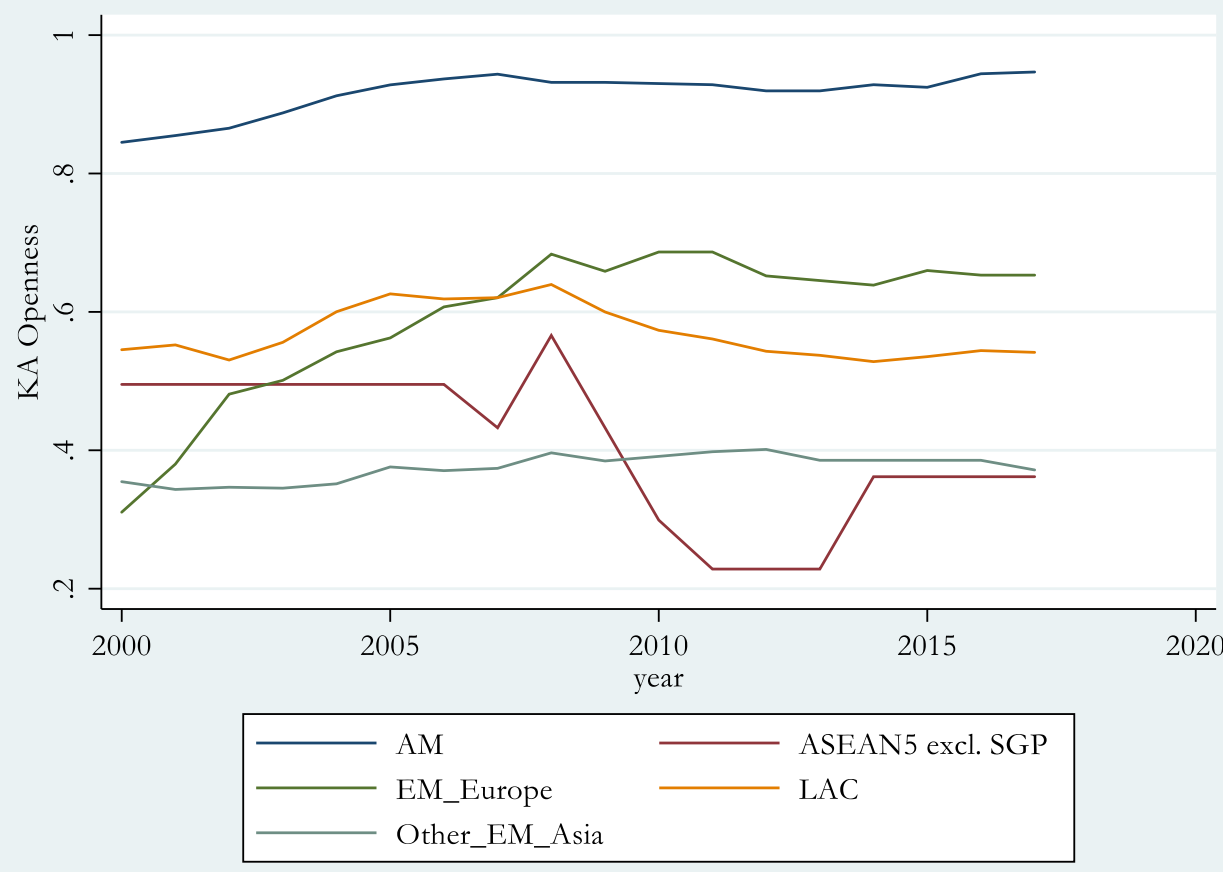

Figure A4.2. Capital Account Openness in ASEAN5, 2000-2017

(normalized Chinn-Ito Index)

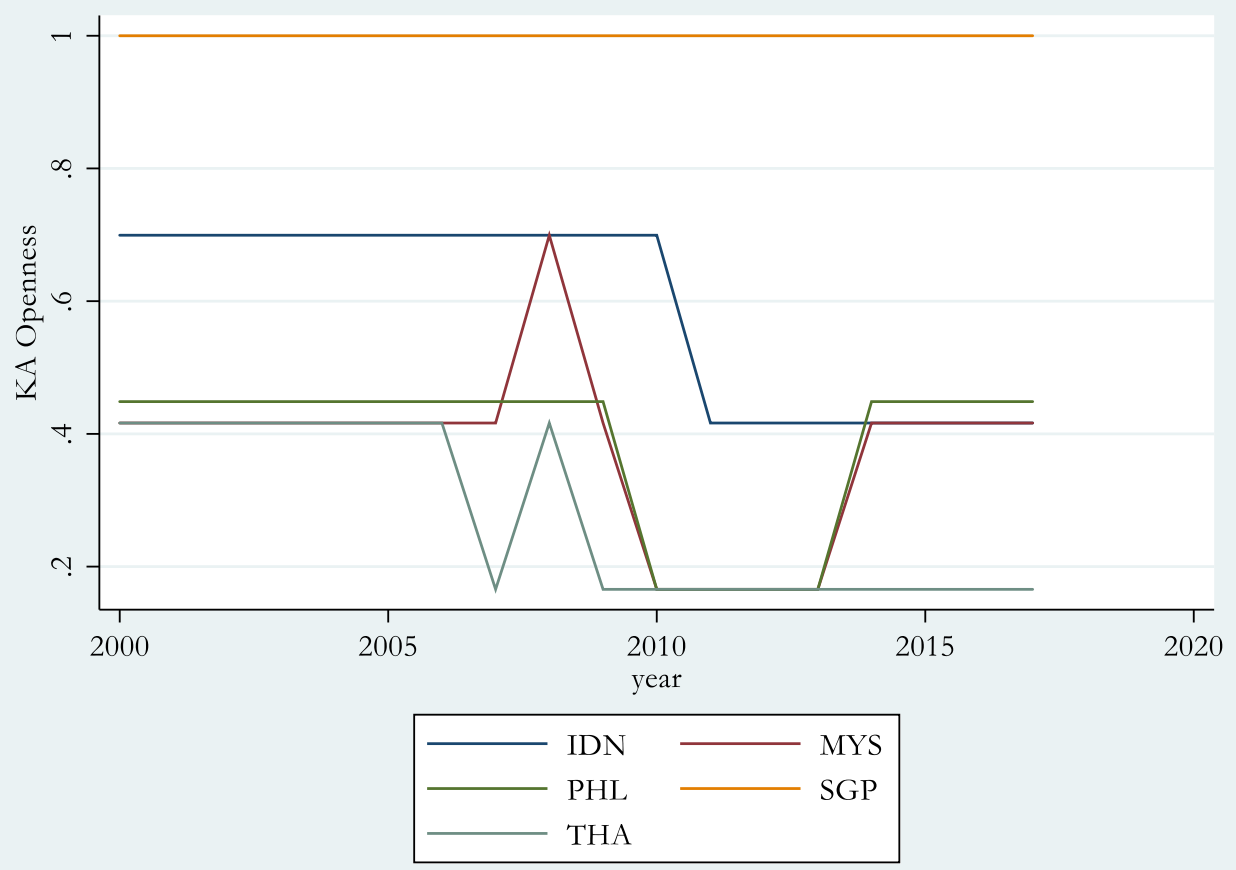

Sources: WorldScope and IMF staff calculation. 


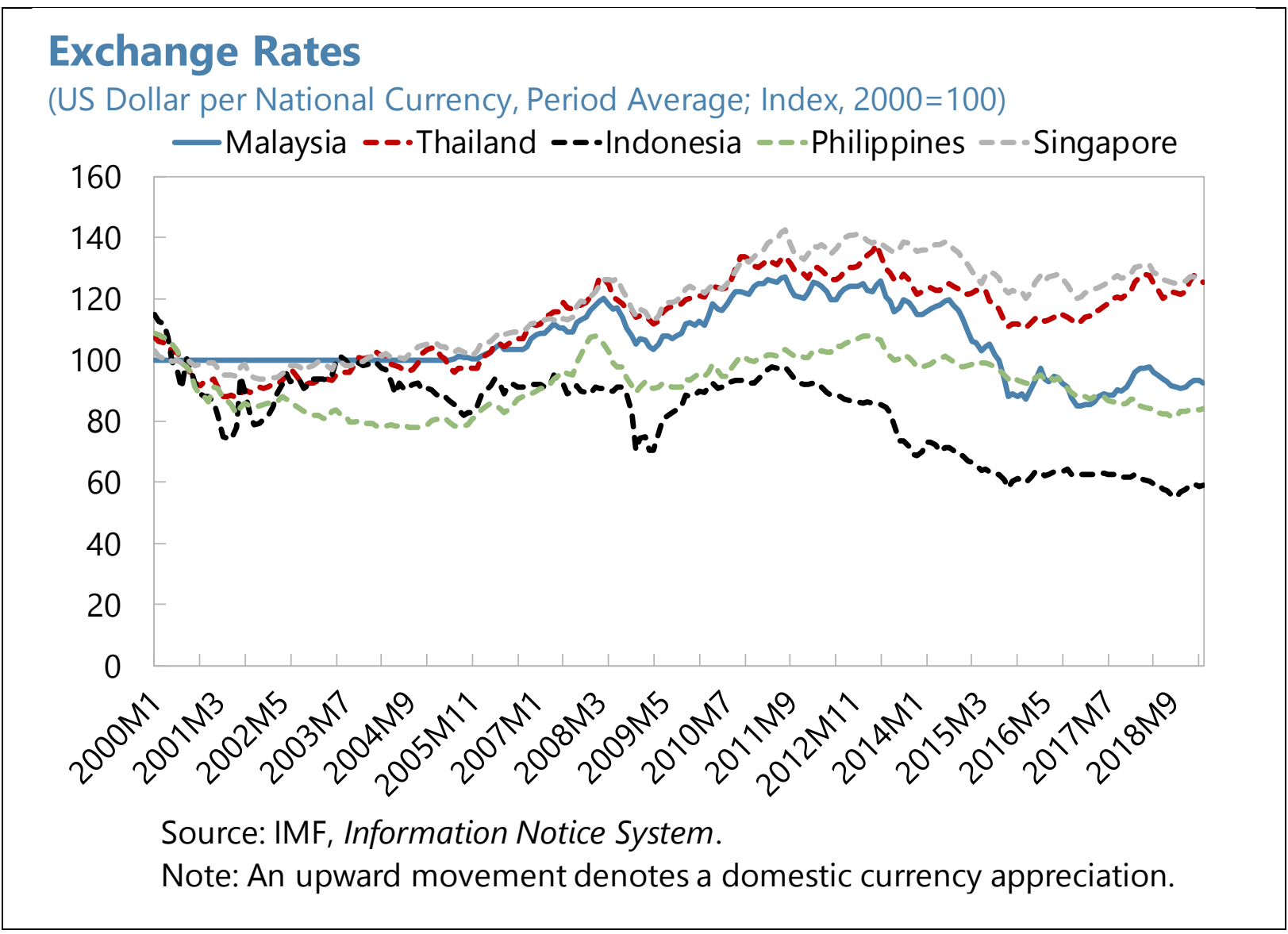


Figure A6.1. Credit-to-GDP Ratio, 2000-2017

(in percent, unweighted average by country group)

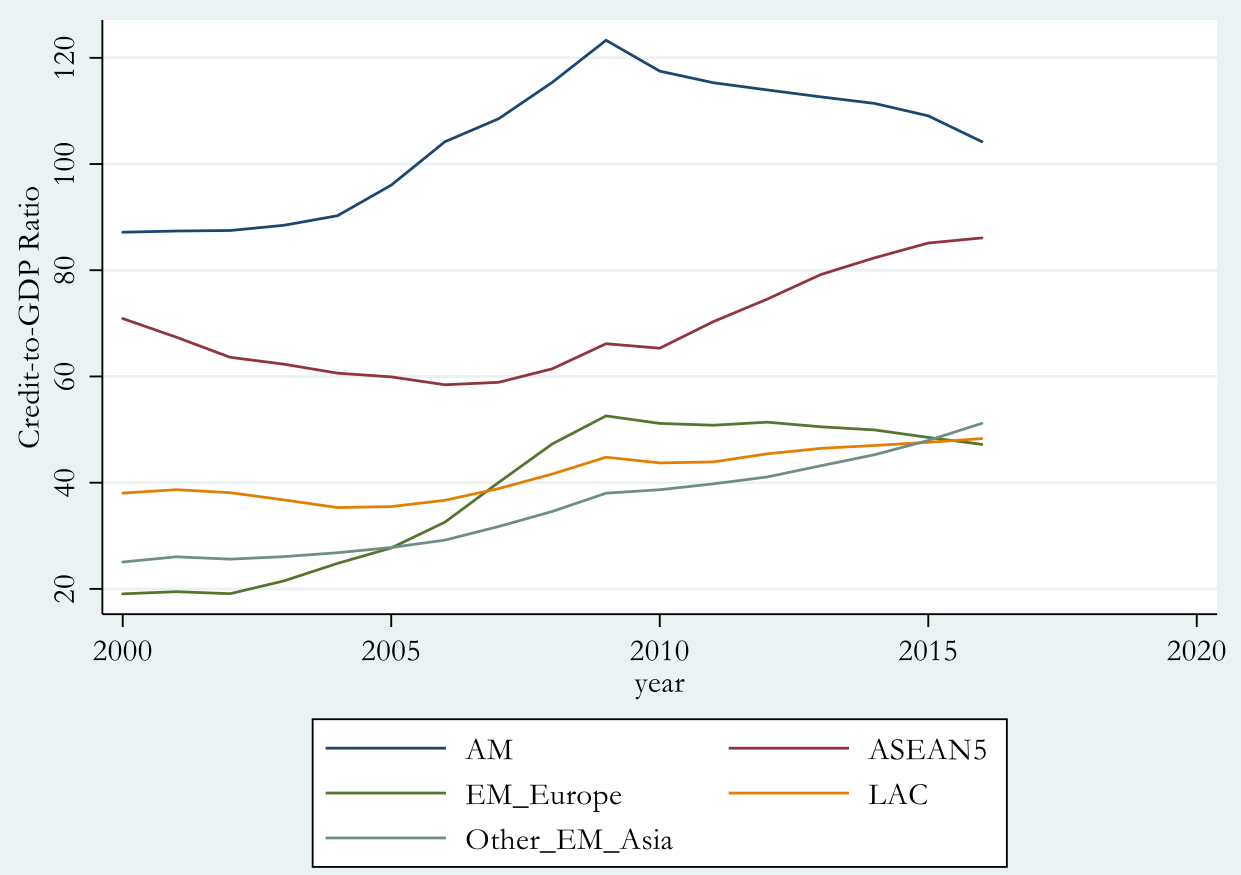

Figure A6.2. Credit-to-GDP Ratio in ASEAN5, 2000-2017 (in percent)

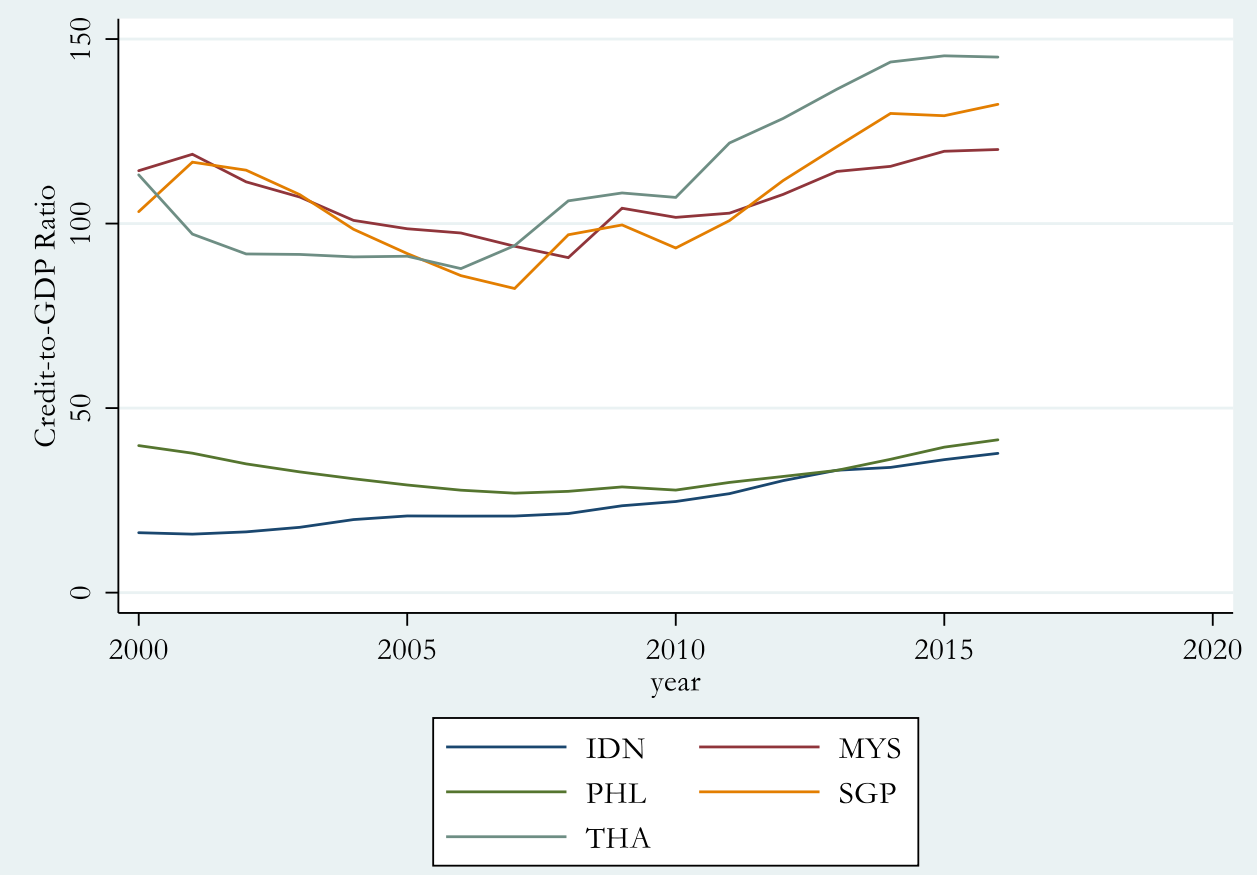

Sources: WorldScope and IMF staff calculation. 
Figure A6.3. Total Capitalization, 2000-2017

(in percent, unweighted average by country group)

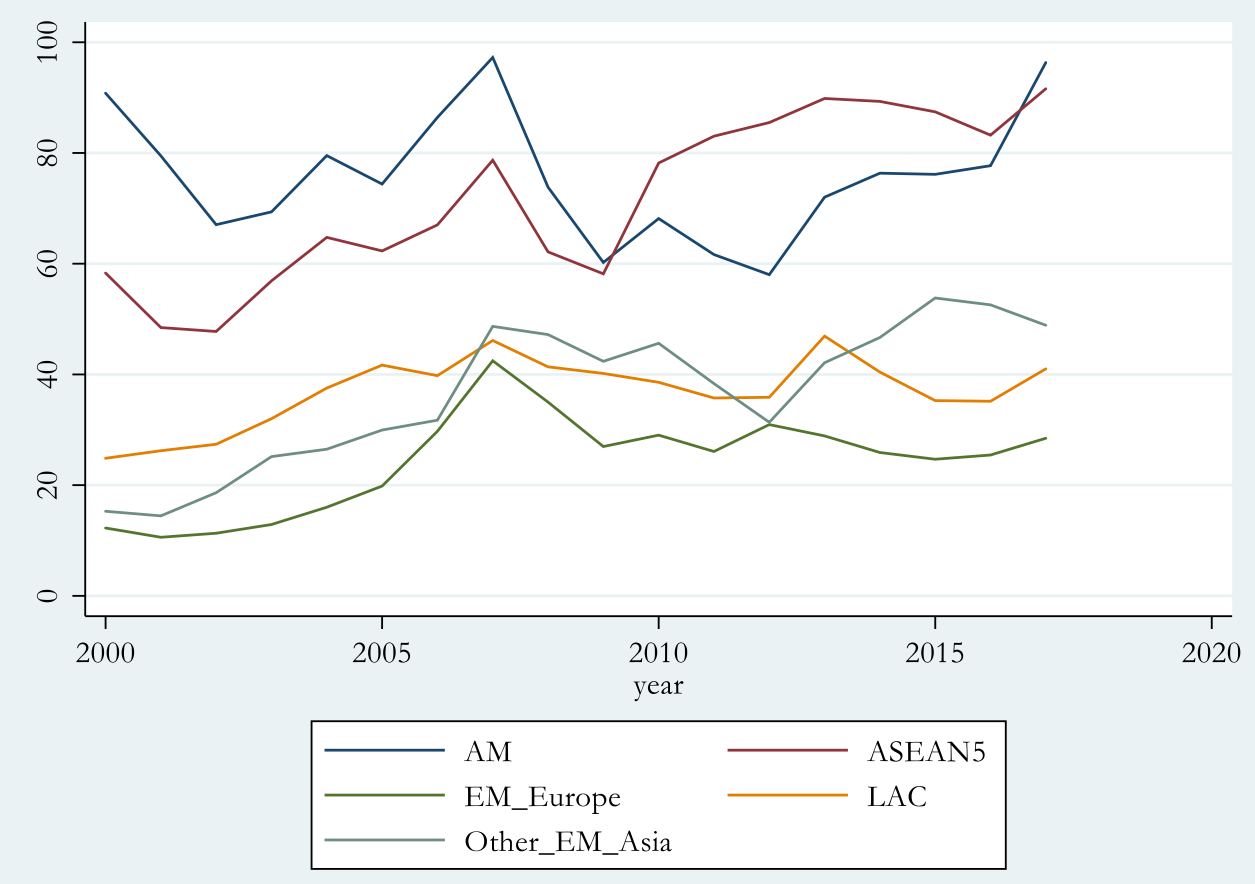

Figure A6.4. Spread between Lending and Deposit Rates, 2000-2017 (in percent, unweighted average by country group)

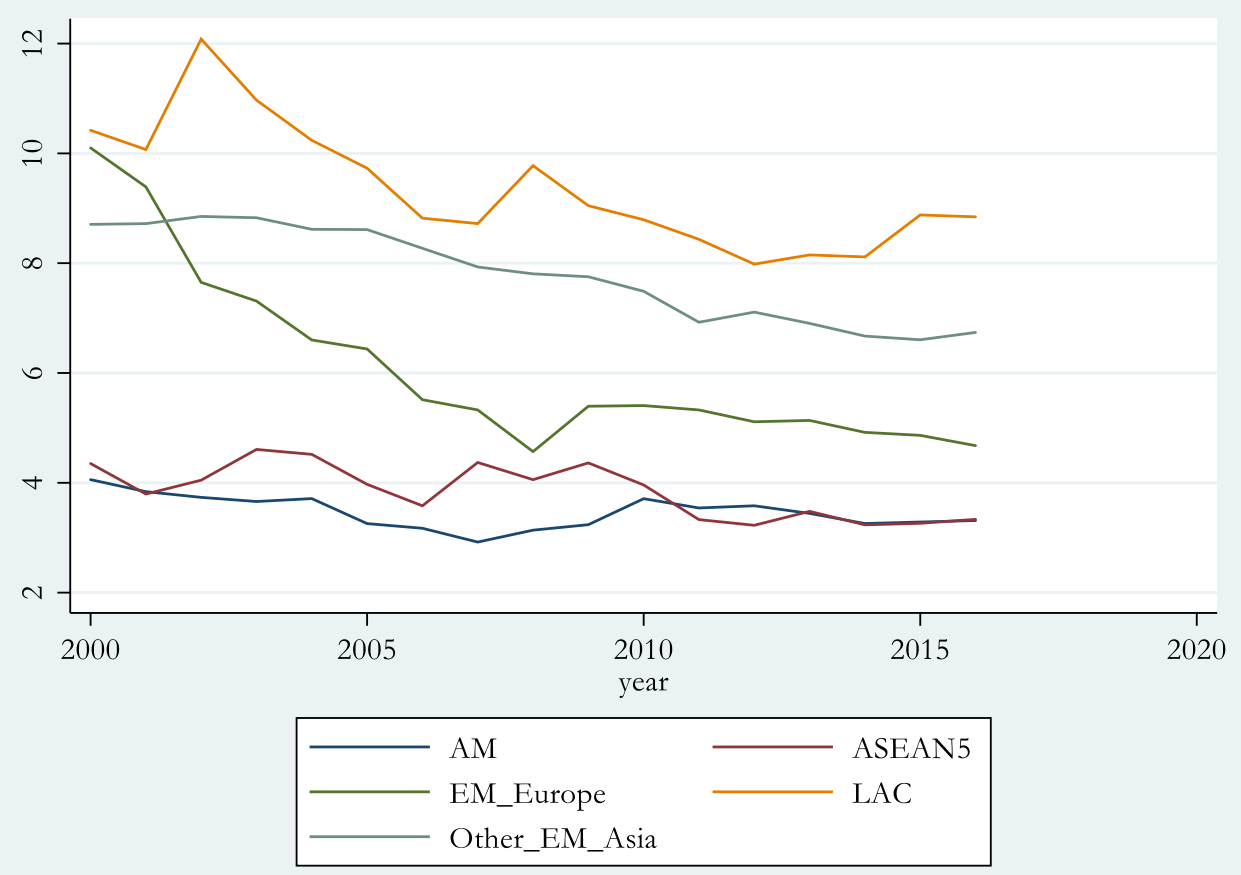

Sources: WorldScope and IMF staff calculation. 
Figure A6.5. Total Capitalization, 2000-2017

(in percent, unweighted average by country group)

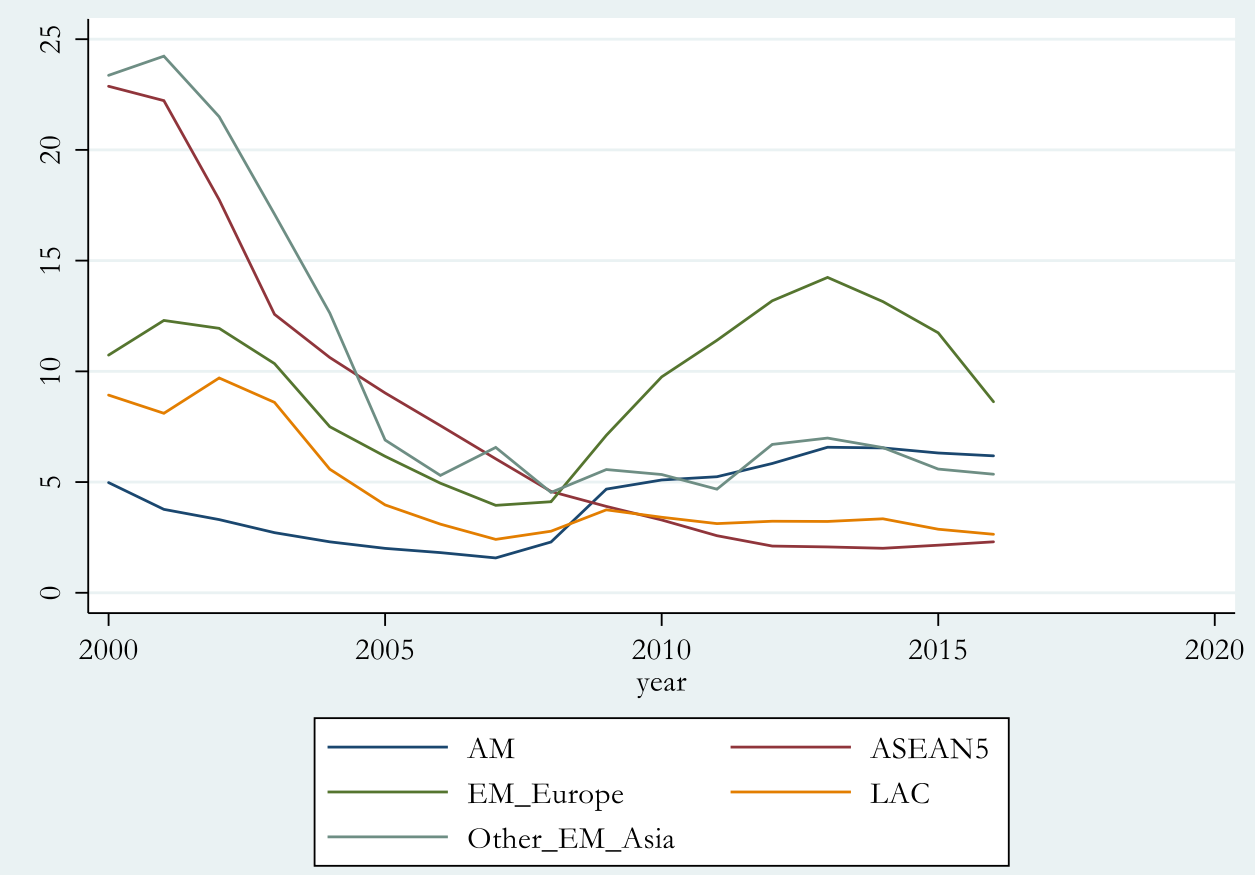

Figure A6.6. Concentration of the Largest Three Banks, 2000-2017 (in percent, unweighted average by country group)

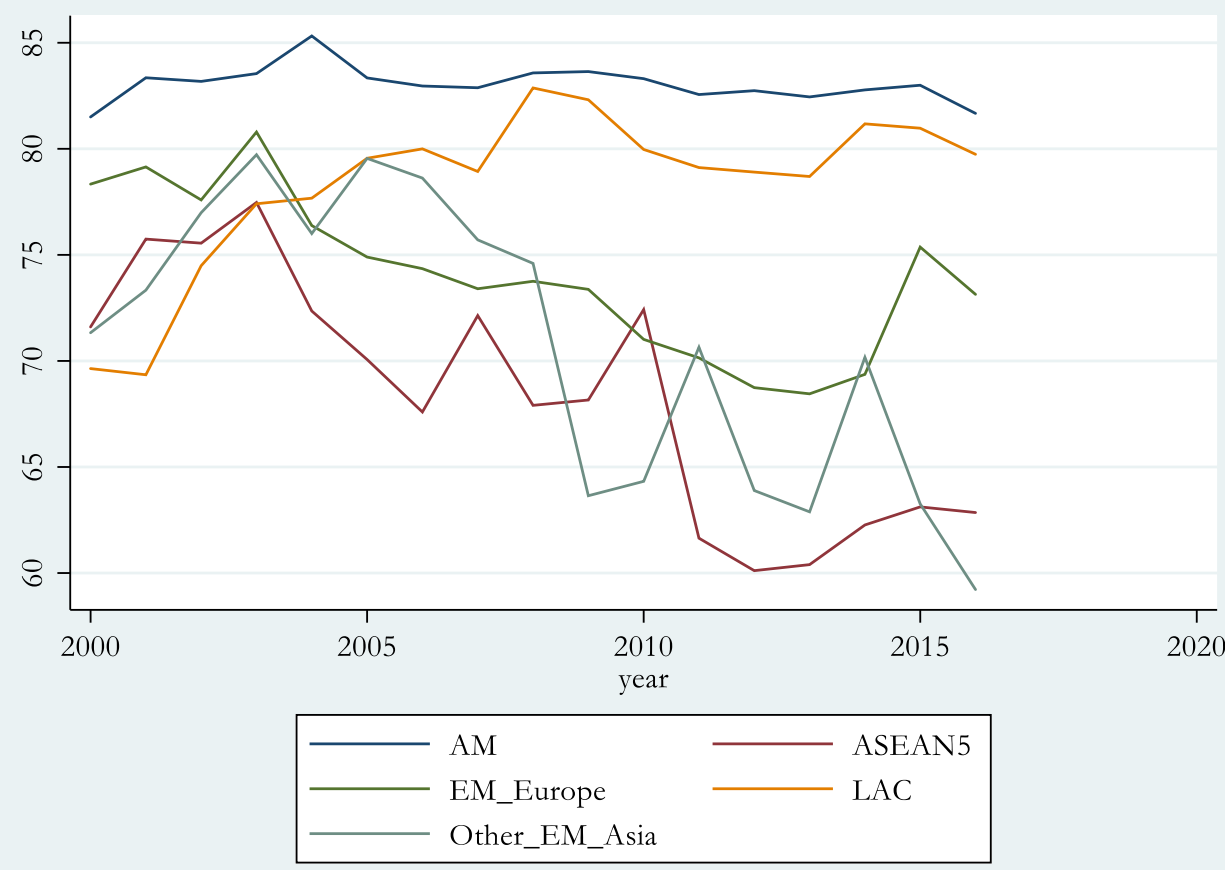

Sources: WorldScope and IMF staff calculation. 

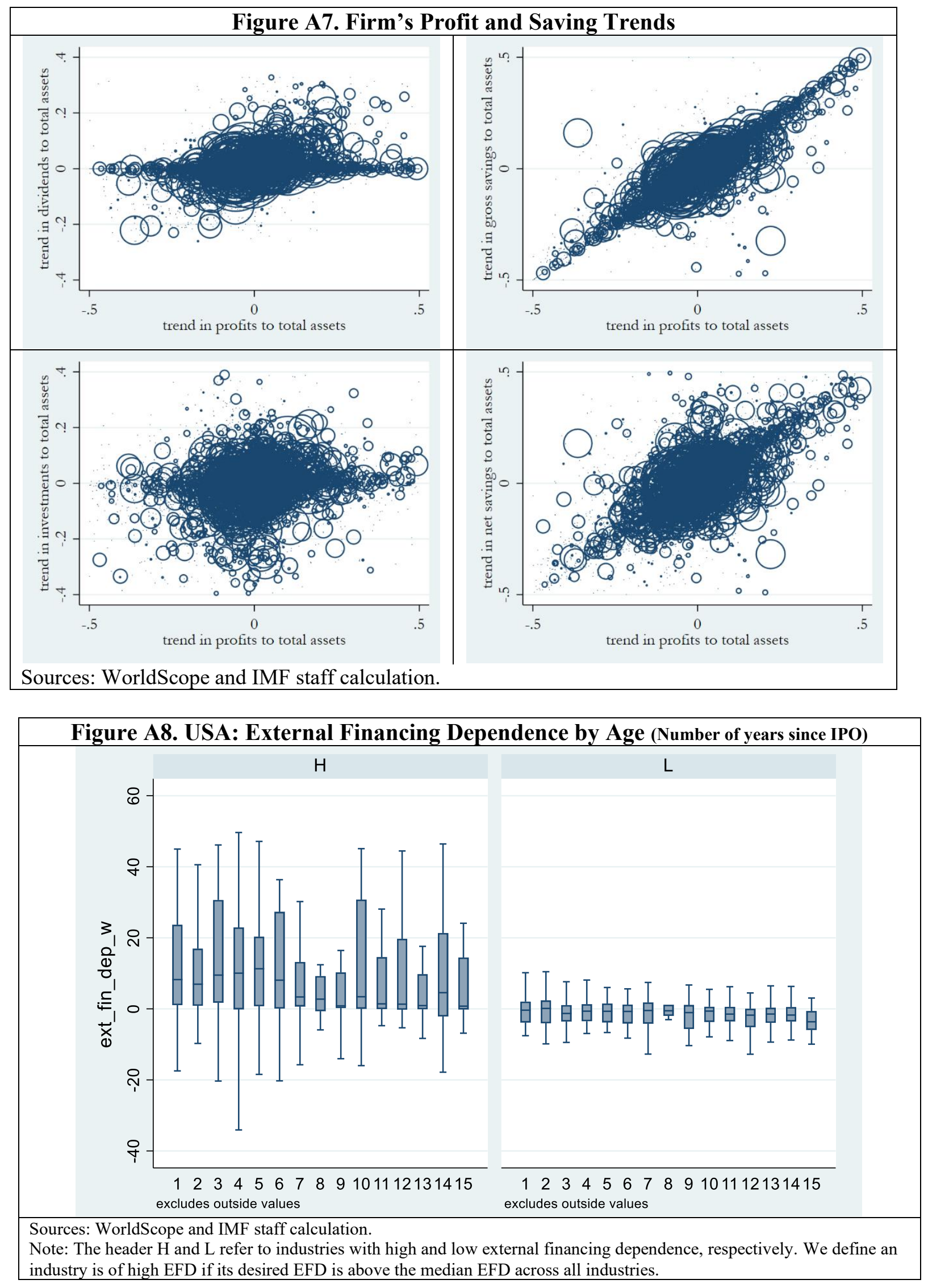

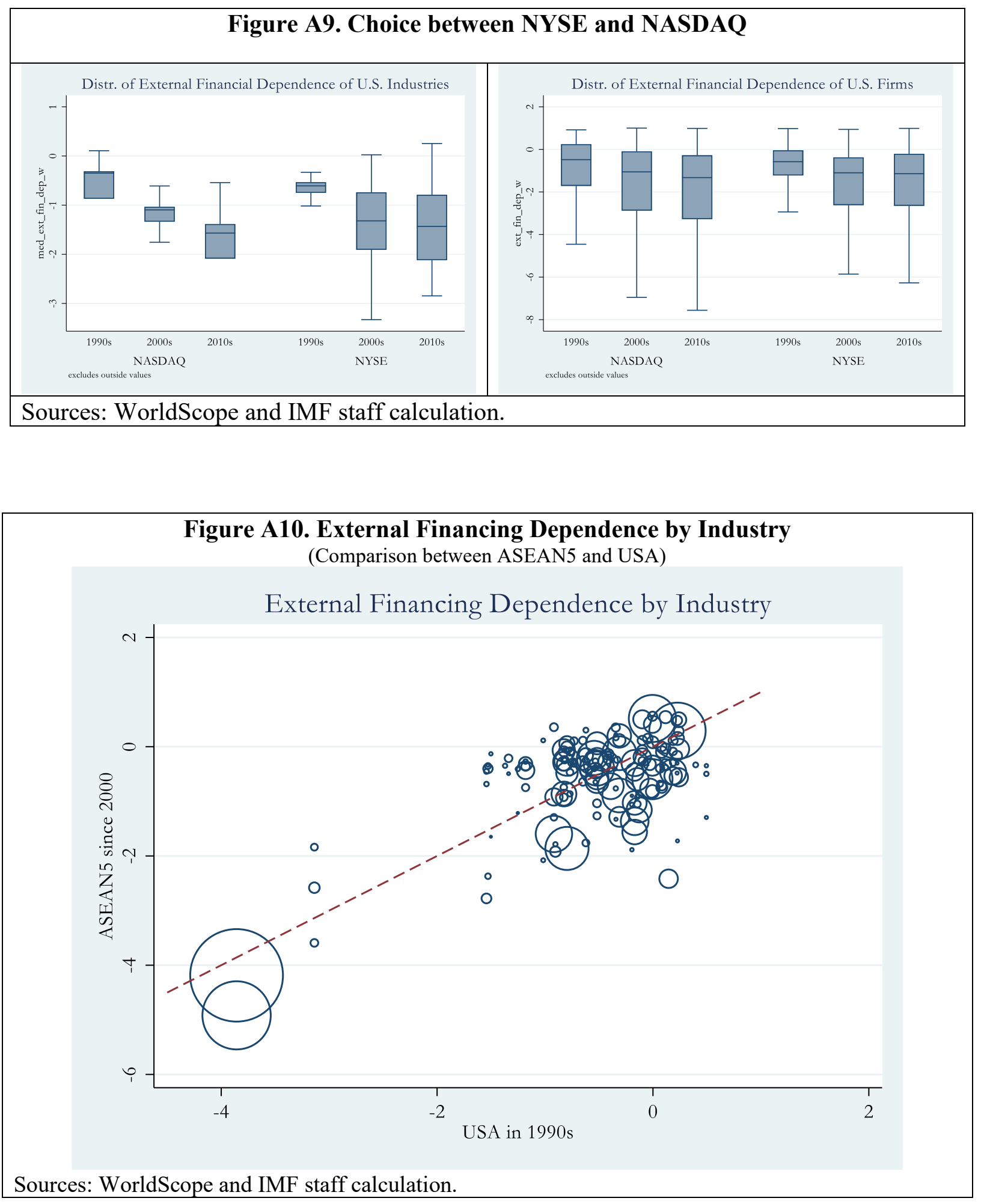
Figure A11. USA: Evolution of External Financing Dependence by Industry
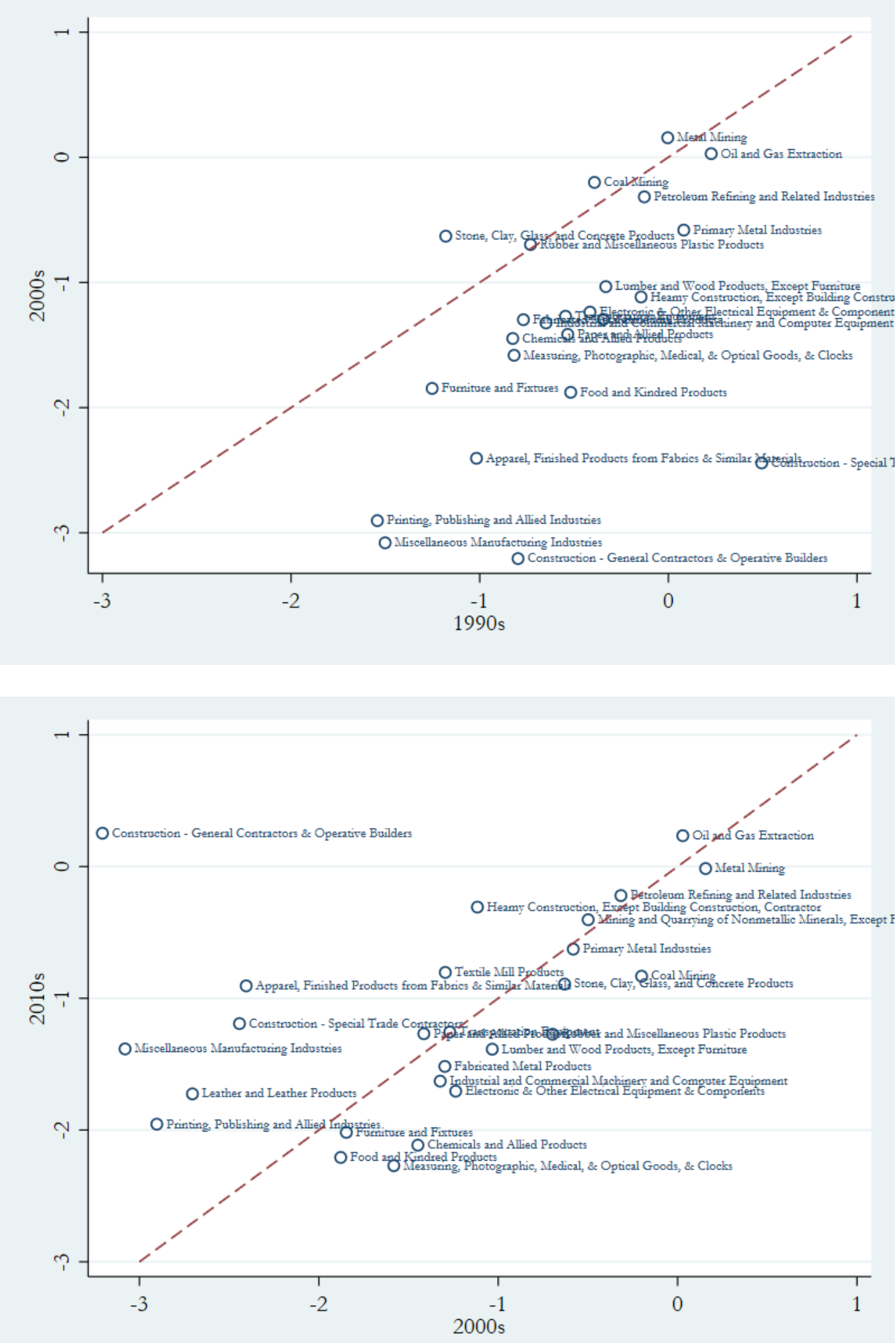

Sources: WorldScope and IMF staff calculation. 
APPENDIX II. TABLES

Table A1: Data Coverage

\begin{tabular}{|cccccc|}
\hline & \multicolumn{5}{c|}{ (in percent of GDP) } \\
\cline { 3 - 6 } Country & No. of Firms & Total Asset & Gross Saving & Investment & Net Saving \\
\hline IDN & 451 & $28.5 \%$ & $1.8 \%$ & $1.4 \%$ & $0.3 \%$ \\
MYS & 820 & $170.2 \%$ & $9.9 \%$ & $8.4 \%$ & $1.5 \%$ \\
PHL & 163 & $79.2 \%$ & $4.1 \%$ & $3.2 \%$ & $0.9 \%$ \\
SGP & 516 & $110.9 \%$ & $3.5 \%$ & $4.2 \%$ & $-0.7 \%$ \\
THA & 580 & $83.3 \%$ & $5.9 \%$ & $4.3 \%$ & $1.6 \%$ \\
\hline Avg. & 506 & $75.0 \%$ & $4.1 \%$ & $3.5 \%$ & $0.7 \%$ \\
\hline \multicolumn{7}{r}{} \\
\hline
\end{tabular}


Table A2: Firm growth and Financial System Development

\begin{tabular}{|c|c|c|c|c|c|}
\hline & (1) & (2) & (3) & (4) & (5) \\
\hline L.corp_growth & $\begin{array}{l}0.0900 \star \star \star \\
(9.92)\end{array}$ & $\begin{array}{l}0.104 \star \star \star \\
(12.00)\end{array}$ & $\begin{array}{l}0.0969 \star \star \star \\
(10.64)\end{array}$ & $\begin{array}{l}0.0927 \star \star \star \\
(10.26)\end{array}$ & $\begin{array}{l}0.105 \star \star \star \\
(11.41)\end{array}$ \\
\hline L2.corp_growth & $\begin{array}{l}0.0464 \star \star \star \\
(6.54)\end{array}$ & $\begin{array}{l}0.0487 \star \star \star \\
(7.16)\end{array}$ & $\begin{array}{l}0.0508 \star \star \star \\
(7.13)\end{array}$ & $\begin{array}{l}0.0458 * \star \star \\
(6.46)\end{array}$ & $\begin{array}{l}0.0499 \star \star \star \\
(6.92)\end{array}$ \\
\hline $\log$ asset & $\begin{array}{l}0.912 \star \star \star \\
(98.50)\end{array}$ & $\begin{array}{l}0.898 \star \star \star \\
(99.38)\end{array}$ & $\begin{array}{l}0.908 \star \star \star \\
(97.48)\end{array}$ & $\begin{array}{l}0.913 \star \star \star \\
(98.21)\end{array}$ & $\begin{array}{l}0.908 * \star \star \\
(96.50)\end{array}$ \\
\hline age quartile & $\begin{array}{l}-0.117 \star \star \star \\
(-9.34)\end{array}$ & $\begin{array}{l}-0.139 \star \star \star \\
(-11.75)\end{array}$ & $\begin{array}{l}-0.134 \star \star \star \\
(-10.70)\end{array}$ & $\begin{array}{l}-0.118 \star \star \star \\
(-9.30)\end{array}$ & $\begin{array}{l}-0.134 \star \star \star \\
(-10.60)\end{array}$ \\
\hline Tobin's Q & $\begin{array}{c}-0.000305 * \star \star \\
(-3.43)\end{array}$ & $\begin{array}{c}-0.000318 * \star \star \\
(-3.58)\end{array}$ & $\begin{array}{c}-0.000301 * k \star \\
(-3.36)\end{array}$ & $\begin{array}{c}-0.000295 \star \star \star \\
(-3.32)\end{array}$ & $\begin{array}{c}-0.000303 * k \star \\
(-3.39)\end{array}$ \\
\hline industrial profit & $\begin{array}{l}0.208 \star \star \\
(3.27)\end{array}$ & $\begin{array}{l}0.236 \star \star \star \\
(3.81)\end{array}$ & $\begin{array}{l}0.263 \star \star \star \\
(4.11)\end{array}$ & $\begin{array}{l}0.270 \star \star \star \\
(4.24)\end{array}$ & $\begin{array}{l}0.243 \star \star \star \\
(3.65)\end{array}$ \\
\hline industrial profit^2 & $\begin{array}{r}-0.00904 \\
(-0.28)\end{array}$ & $\begin{array}{l}-0.0121 \\
(-0.38)\end{array}$ & $\begin{array}{l}-0.0231 \\
(-0.71)\end{array}$ & $\begin{array}{l}-0.0240 \\
(-0.74)\end{array}$ & $\begin{array}{l}-0.0144 \\
(-0.44)\end{array}$ \\
\hline EFD $x$ Credit-to-GDP & $\begin{array}{l}0.00518 \star \star \star \\
(9.07)\end{array}$ & & & & \\
\hline EFD x Capitalization & & $\begin{array}{r}-0.000326 \\
(-1.43)\end{array}$ & & & \\
\hline EFD $\mathrm{x}$ Interest spr d & & & $\begin{array}{l}-0.0213 \star \\
(-2.36)\end{array}$ & & \\
\hline EFD $x$ Bank NLP rate & & & & $\begin{array}{l}-0.0196 \star \star \star \\
(-8.86)\end{array}$ & \\
\hline EFD $x$ Bank Concent $\sim \mathrm{n}$ & & & & & $\begin{array}{c}-0.00125^{\star} \\
(-2.57)\end{array}$ \\
\hline Constant & $\begin{array}{l}-11.39 \star \star \star \\
(-92 \cdot 53)\end{array}$ & $\begin{array}{l}-11.46 \star \star \star \\
(-95.68)\end{array}$ & $\begin{array}{l}-11.58 \star \star \star \\
(-92.45)\end{array}$ & $\begin{array}{l}-11.70 * \star \star \\
(-93.82)\end{array}$ & $\begin{array}{l}-11.62 \star \star \star \\
(-90.95)\end{array}$ \\
\hline Observations & 12692 & 13687 & 12692 & 12692 & 12351 \\
\hline
\end{tabular}

t statistics in parentheses

* $\mathrm{p}<0.05, * \star \mathrm{p}<0.01, * * * \mathrm{p}<0.001$ 
Table A3: Firm/industry Characteristics and Net Saving

\begin{tabular}{|c|c|c|c|}
\hline & (1) & (2) & (3) \\
\hline L. net saving rate & $\begin{array}{l}0.178 * \star \star \\
(15.86)\end{array}$ & $\begin{array}{l}0.177 \star \star \star \\
(15.82)\end{array}$ & $\begin{array}{l}0.178 \star \star \star \\
(15.87)\end{array}$ \\
\hline L2. net saving rate & $\begin{array}{l}0.0228 \text { * } \\
(2.47)\end{array}$ & $\begin{array}{l}0.0226 \star \\
(2.45)\end{array}$ & $\begin{array}{l}0.0229 \star \\
(2.48)\end{array}$ \\
\hline $\log$ asset & $\begin{array}{l}0.108 \star \star \star \\
(30.19)\end{array}$ & $\begin{array}{l}0.109 \star \star \star \\
(30.90)\end{array}$ & $\begin{array}{l}0.108 * \star \star \\
(30.10)\end{array}$ \\
\hline age quartile & $\begin{array}{l}-0.0225 \star \star \star \\
(-4.37)\end{array}$ & $\begin{array}{l}-0.0227 \star \star \star \\
(-4.40)\end{array}$ & $\begin{array}{l}-0.0225 \star \star \star \\
(-4.37)\end{array}$ \\
\hline industrial profit & $\begin{array}{l}0.324 \star \star \star \\
(15.20)\end{array}$ & $\begin{array}{l}0.325 * \star \star \\
(15.23)\end{array}$ & $\begin{array}{l}0.324 \star \star \star \\
(15.11)\end{array}$ \\
\hline industrial profit^ 2 & $\begin{array}{l}-0.173 \star \star \star \\
(-15.61)\end{array}$ & $\begin{array}{l}-0.172 \star \star \star \\
(-15.21)\end{array}$ & $\begin{array}{l}-0.174 \star \star \star \\
(-15.29)\end{array}$ \\
\hline Tobin's $Q$ & $\begin{array}{c}-0.000133 \star \star \\
(-2.71)\end{array}$ & & $\begin{array}{r}-0.000133 \\
(-1.69)\end{array}$ \\
\hline EFD $x$ Tobin's $Q$ & & $\begin{array}{c}0.000167 \star \\
(2.19)\end{array}$ & $\begin{array}{r}0.00000420 \\
(0.03)\end{array}$ \\
\hline Constant & $\begin{array}{l}-1.402 \star \star \star \\
(-29.36)\end{array}$ & $\begin{array}{l}-1.418 \star \star \star \\
(-30.02)\end{array}$ & $\begin{array}{l}-1.403 \star \star \star \\
(-29.27)\end{array}$ \\
\hline Observations & 14914 & 14914 & 14914 \\
\hline
\end{tabular}

$t$ statistics in parentheses

* $\mathrm{p}<0.05,{ }^{\star *} \mathrm{p}<0.01,{ }^{* \star *} \mathrm{p}<0.001$ 
Table A4. Net Saving Rate: KA Openness, External Financing Dependence, and Export Orientation

\begin{tabular}{|c|c|c|c|c|c|}
\hline & (1) & (2) & (3) & (4) & (5) \\
\hline L.net saving rate & $\begin{array}{l}0.178 \star \star \star \\
(15.86)\end{array}$ & $\begin{array}{l}0.176 \star \star \star \\
(15.76)\end{array}$ & $\begin{array}{l}0.176 \star \star \star \\
(15.71)\end{array}$ & $\begin{array}{l}0.176 \star \star \star \\
(15.71)\end{array}$ & $\begin{array}{l}0.167 \star \star \star \\
(12.40)\end{array}$ \\
\hline L2. net saving rate & $\begin{array}{l}0.0228 \star \\
(2.47)\end{array}$ & $\begin{array}{l}0.0217 \star \\
(2.36)\end{array}$ & $\begin{array}{l}0.0219 \star \\
(2.38)\end{array}$ & $\begin{array}{l}0.0216 \star \\
(2.34)\end{array}$ & $\begin{array}{l}0.0104 \\
(0.96)\end{array}$ \\
\hline $\log$ asset & $\begin{array}{l}0.108 \star \star \star \\
(30.19)\end{array}$ & $\begin{array}{l}0.108 \star \star \star \\
(30.25)\end{array}$ & $\begin{array}{l}0.108 * \star \star \\
(30.29)\end{array}$ & $\begin{array}{l}0.108 \star \star \star \\
(30.29)\end{array}$ & $\begin{array}{l}0.104 \star \star \star \\
(26.01)\end{array}$ \\
\hline age quartile & $\begin{array}{l}-0.0225 \star \star \star \\
(-4.37)\end{array}$ & $\begin{array}{l}-0.0231 \star \star \star \\
(-4.47)\end{array}$ & $\begin{array}{l}-0.0228 \star \star \star \\
(-4.42)\end{array}$ & $\begin{array}{l}-0.0230 \star \star \star \\
(-4.46)\end{array}$ & $\begin{array}{l}-0.0265 * \star \star \\
(-4.59)\end{array}$ \\
\hline Tobin's Q & $\begin{array}{c}-0.000133 \star \star \\
(-2.71)\end{array}$ & $\begin{array}{c}-0.000133^{\star \star} \star \\
(-2.72)\end{array}$ & $\begin{array}{c}-0.000132 \star \star \\
(-2.70)\end{array}$ & $\begin{array}{c}-0.000133 \star \star \\
(-2.71)\end{array}$ & $\begin{array}{c}-0.000127 \star \star \\
(-2.63)\end{array}$ \\
\hline industrial profit & $\begin{array}{l}0.324 \star \star \star \\
(15.20)\end{array}$ & $\begin{array}{l}0.323 \star \star \star \\
(15.17)\end{array}$ & $\begin{array}{l}0.326 \star \star \star \\
(15.32)\end{array}$ & $\begin{array}{l}0.324 \star \star \star \\
(15.25)\end{array}$ & $\begin{array}{l}0.354 \star \star \star \\
(12.04)\end{array}$ \\
\hline industrial profit^2 & $\begin{array}{l}-0.173 \star \star \star \\
(-15.61)\end{array}$ & $\begin{array}{l}-0.174 \star \star \star \\
(-15 \cdot 70)\end{array}$ & $\begin{array}{l}-0.175 \star \star \star \\
(-15.76)\end{array}$ & $\begin{array}{l}-0.175 \star \star \star \\
(-15.76)\end{array}$ & $\begin{array}{l}-0.194 \star \star \star \\
(-13.60)\end{array}$ \\
\hline KA openness & & $\begin{array}{l}-0.0546 \star \star \star \\
(-4.10)\end{array}$ & & $\begin{array}{l}-0.0351 \star \\
(-2.14)\end{array}$ & \\
\hline EFD $x$ KA openness & & & $\begin{array}{l}0.0577 \star \star \star \\
(4.02)\end{array}$ & $\begin{array}{l}0.0357 \star \\
(2.01)\end{array}$ & \\
\hline Export Ori. $\mathrm{x}$ KA o s & & & & & $\begin{array}{l}-0.0739 \star \star \star \\
(-3.85)\end{array}$ \\
\hline Constant & $\begin{array}{l}-1.402 \star \star \star \\
(-29.36)\end{array}$ & $\begin{array}{l}-1.372 \star \star \star \\
(-28.43)\end{array}$ & $\begin{array}{l}-1.390 \star \star \star \\
(-29.07)\end{array}$ & $\begin{array}{l}-1.375 \star \star \star \\
(-28.49)\end{array}$ & $\begin{array}{l}-1 \cdot 311 \star \star \star \\
(-24 \cdot 37)\end{array}$ \\
\hline Observations & 14914 & 14914 & 14914 & 14914 & 11159 \\
\hline
\end{tabular}

t statistics in parentheses

* $\mathrm{p}<0.05, * \star \mathrm{p}<0.01$, $\star * \star \mathrm{k}<0.001$ 
Table A5. Interaction between KA Openness and External Financing Dependence by Export Orientation

\begin{tabular}{|c|c|c|c|c|c|c|c|c|c|}
\hline & (1) & (2) & (3) & (4) & (5) & (6) & (7) & (8) & (9) \\
\hline L. net saving rate & $\begin{array}{l}0.183 \star \star \star \\
(17.99)\end{array}$ & $\begin{array}{l}0.110 * \star \star \\
(3.87)\end{array}$ & $\begin{array}{r}-0.0579 \\
(-1.22)\end{array}$ & $\begin{array}{l}0.0698 \\
(1.39)\end{array}$ & $\begin{array}{l}-0.0520 \\
(-1.29)\end{array}$ & $\begin{array}{l}0.0324 \\
(0.93)\end{array}$ & $\begin{array}{l}-0.0674 \text { * } \\
(-2.02)\end{array}$ & $\begin{array}{l}0.0262 \\
(0.87)\end{array}$ & $\begin{array}{r}-0.00762 \\
(-0.16)\end{array}$ \\
\hline L2. net saving rate & & $\begin{array}{l}0.0123 \\
(0.58)\end{array}$ & $\begin{array}{l}-0.124 \star \star \\
(-3.15)\end{array}$ & $\begin{array}{l}-0.0687 \\
(-1.69)\end{array}$ & $\begin{array}{l}-0.0893 \star \star \\
(-3.01)\end{array}$ & $\begin{array}{l}-0.0778 \text { * } \\
(-2.83)\end{array}$ & $\begin{array}{l}-0.0681 \star \star \\
(-2.89)\end{array}$ & $\begin{array}{l}-0.0855 \star \star \star \\
(-3.54)\end{array}$ & $\begin{array}{r}-0.00128 \\
(-0.03)\end{array}$ \\
\hline $\log$ asset & $\begin{array}{l}0.103 \star \star \star \\
(30.47)\end{array}$ & $\begin{array}{l}0.0413 * \star \star \\
(7.24)\end{array}$ & $\begin{array}{l}0.119 * \star \star \\
(8.70)\end{array}$ & $\begin{array}{l}0.0398 * \star \\
(3.06)\end{array}$ & $\begin{array}{l}0.0685 \star \star \star \\
(6.51)\end{array}$ & $\begin{array}{l}0.151 \star \star \star \\
(15.41)\end{array}$ & $\begin{array}{l}0.130 \star \star \star \\
(13.80)\end{array}$ & $\begin{array}{l}0.129 \star \star \star \\
(11.79)\end{array}$ & $\begin{array}{l}0.204 k \star \star \\
(12.78)\end{array}$ \\
\hline age quartile & $\begin{array}{l}-0.0187 \star \star \star \\
(-3.70)\end{array}$ & $\begin{array}{l}-0.0125 \\
(-0.90)\end{array}$ & $\begin{array}{l}-0.0203 \\
(-1.00)\end{array}$ & $\begin{array}{l}-0.0387 \star \\
(-2.19)\end{array}$ & $\begin{array}{l}-0.0305 \star \star \\
(-2.66)\end{array}$ & $\begin{array}{l}-0.0638 \star \star \star \\
(-4.36)\end{array}$ & $\begin{array}{l}-0.0220 \\
(-1.86)\end{array}$ & $\begin{array}{r}-0.00100 \\
(-0.08)\end{array}$ & $\begin{array}{l}-0.0178 \\
(-1.14)\end{array}$ \\
\hline Tobin's $Q$ & $\begin{array}{c}-0.000148 \star \star \\
(-2.97)\end{array}$ & $\begin{array}{c}-0.000418 \star \star \star \\
(-3.72)\end{array}$ & $\begin{array}{c}-0.0133 \\
(-1.61)\end{array}$ & $\begin{array}{l}-0.0129 \star \star \star \\
(-7.67)\end{array}$ & $\begin{array}{l}-0.0143 \star \star \\
(-2.60)\end{array}$ & $\begin{array}{c}0.000265 \star \star \\
(2.92)\end{array}$ & $\begin{array}{r}0.000591 \\
(1.90)\end{array}$ & $\begin{array}{c}-0.000245 \star \star \star \\
(-3.42)\end{array}$ & $\begin{array}{r}-0.000708 \\
(-0.08)\end{array}$ \\
\hline industrial profit & $\begin{array}{l}0.303 \star \star \star \\
(14.66)\end{array}$ & $\begin{array}{l}0.460 * \star \star \\
(6.07)\end{array}$ & $\begin{array}{r}0.411 \\
(1.81)\end{array}$ & $\begin{array}{l}0.661 \star \star \star \\
(8.06)\end{array}$ & $\begin{array}{l}0.724 \star \star \star \\
(8.69)\end{array}$ & $\begin{array}{l}0.356 \star \star \star \\
(4.13)\end{array}$ & $\begin{array}{l}0.334 \star \star \star \\
(3.96)\end{array}$ & $\begin{array}{l}0.351 \star \star \star \\
(6.53)\end{array}$ & $\begin{array}{r}0.771 \\
(1.62)\end{array}$ \\
\hline industrial profit^ 2 & $\begin{array}{l}-0.158 \star \star \star \star \\
(-14.58)\end{array}$ & $\begin{array}{l}-0.212 \star \star \star \\
(-8.62)\end{array}$ & $\begin{array}{l}1.758 \\
(1.30)\end{array}$ & $\begin{array}{l}0.0342 \\
(0.41)\end{array}$ & $\begin{array}{l}0.776 \star \\
(2.23)\end{array}$ & $\begin{array}{l}-0.429 \star \star \\
(-3.28)\end{array}$ & $\begin{array}{l}-0.180 \\
(-1.55)\end{array}$ & $\begin{array}{r}0.180 \\
(0.76)\end{array}$ & $\begin{array}{l}-4.499 \\
(-1.52)\end{array}$ \\
\hline EFD $\times$ KA openness & $\begin{array}{l}0.0542 \star * \star \\
(3.77)\end{array}$ & $\begin{array}{c}-0.0173 \\
(-0.41)\end{array}$ & $\begin{array}{l}0.0627 \\
(0.92)\end{array}$ & $\begin{array}{c}-0.0456 \\
(-0.91)\end{array}$ & $\begin{array}{l}-0.0123 \\
(-0.65)\end{array}$ & $\begin{array}{l}0.109 \star \star \star \\
(3.91)\end{array}$ & $\begin{array}{l}0.130 \star \star \star \\
(3.97)\end{array}$ & $\begin{array}{c}0.00608 \\
(0.19)\end{array}$ & $\begin{array}{l}0.225 \star \star \\
(2.61)\end{array}$ \\
\hline Constant & $\begin{array}{l}-1.332 \star \star \star \\
(-29.42)\end{array}$ & $\begin{array}{l}-0.645 \star \star \star \\
(-6.94)\end{array}$ & $\begin{array}{l}-1.755 \star \star \star \\
(-8.70)\end{array}$ & $\begin{array}{l}-0.496 \star \star \\
(-2.65)\end{array}$ & $\begin{array}{l}-0.877 \star \star \star \\
(-6.15)\end{array}$ & 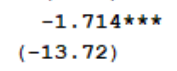 & $\begin{array}{l}-1.573 * \star \star \\
(-13.20)\end{array}$ & $\begin{array}{l}-1.639 \star \star \star \\
(-12.04)\end{array}$ & $\begin{array}{l}-2.429 \star \star \star \\
(-12.18)\end{array}$ \\
\hline Observations & 16560 & 1766 & 598 & 1008 & 1375 & 2146 & 1884 & 2242 & 1125 \\
\hline
\end{tabular}

$t$ statistics in parentheses

$* \mathrm{p}<0.05, * * \mathrm{p}<0.01, * * * \mathrm{p}<0.001$ 
Table A6: Net Saving Rate: ER Flexibility, External Financing Dependence, and Export Orientation

\begin{tabular}{|c|c|c|c|c|c|}
\hline & (1) & $(2)$ & (3) & (4) & $(5)$ \\
\hline L.net saving rate & $\begin{array}{l}0.178 \star \star \star \\
(15.86)\end{array}$ & $\begin{array}{l}0.176 \star \star \star \\
(15.71)\end{array}$ & $\begin{array}{l}0.177 \star \star \star \\
(15.79)\end{array}$ & $\begin{array}{l}0.176 \star \star \star \\
(15.71)\end{array}$ & $\begin{array}{l}0.167 * \star \star \\
(12.37)\end{array}$ \\
\hline L2. net saving rate & $\begin{array}{l}0.0228 \text { * } \\
(2.47)\end{array}$ & $\begin{array}{l}0.0234 \star \\
(2.54)\end{array}$ & $\begin{array}{l}0.0228 \text { * } \\
(2.47)\end{array}$ & $\begin{array}{l}0.0233 \star \\
(2.53)\end{array}$ & $\begin{array}{c}0.0124 \\
(1.14)\end{array}$ \\
\hline $\log$ asset & $\begin{array}{l}0.108 \star \star \star \\
(30.19)\end{array}$ & $\begin{array}{l}0.108 \star \star \star \\
(30.28)\end{array}$ & $\begin{array}{l}0.108 \star \star \star \\
(30.24)\end{array}$ & $\begin{array}{l}0.108 \star \star \star \\
(30.28)\end{array}$ & $\begin{array}{l}0.104 * \star \star \\
(25.99)\end{array}$ \\
\hline age quartile & $\begin{array}{l}-0.0225 \star \star \star \\
(-4.37)\end{array}$ & $\begin{array}{l}-0.0224 \star \star \star \\
(-4.34)\end{array}$ & $\begin{array}{l}-0.0225 \star \star \star \\
(-4.35)\end{array}$ & $\begin{array}{l}-0.0224 \star \star \star \\
(-4.34)\end{array}$ & $\begin{array}{l}-0.0254 \star \star \star \\
(-4.41)\end{array}$ \\
\hline Tobin's $Q$ & $\begin{array}{c}-0.000133 \star \star \\
(-2.71)\end{array}$ & $\begin{array}{c}-0.000130 \star \star \\
(-2.66)\end{array}$ & $\begin{array}{c}-0.000131 \star \star \\
(-2.68)\end{array}$ & $\begin{array}{c}-0.000130 \star \star \\
(-2.66)\end{array}$ & $\begin{array}{c}-0.000124 \text { * } \\
(-2.57)\end{array}$ \\
\hline industrial profit & $\begin{array}{l}0.324 \star \star \star \\
(15 \cdot 20)\end{array}$ & $\begin{array}{l}0.315 \star \star \star \\
(14.68)\end{array}$ & $\begin{array}{l}0.319 \star \star \star \\
(14.93)\end{array}$ & $\begin{array}{l}0.315 \star \star \star \\
(14.66)\end{array}$ & $\begin{array}{l}0.337 \star \star \star \\
(11.22)\end{array}$ \\
\hline industrial profit`^2 & $\begin{array}{l}-0.173 \star \star \star \\
(-15.61)\end{array}$ & $\begin{array}{l}-0.172 \star \star \star \\
(-15.45)\end{array}$ & $\begin{array}{l}-0.172 \star \star \star \\
(-15.52)\end{array}$ & $\begin{array}{l}-0.172 \star \star \star \\
(-15.44)\end{array}$ & $\begin{array}{l}-0.189 \star \star \star \\
(-13 \cdot 10)\end{array}$ \\
\hline ER deprec. ( $\left.\frac{\Omega}{6}\right)$ & & $\begin{array}{l}-0.0731 \star \star \\
(-2.88)\end{array}$ & & $\begin{array}{l}-0.0637 \star \\
(-2.08)\end{array}$ & \\
\hline EFD x ER deprec. $\left(\frac{\%}{8}\right)$ & & & $\begin{array}{l}0.0577 \star \\
(2.07)\end{array}$ & $\begin{array}{c}0.0183 \\
(0.54)\end{array}$ & \\
\hline Export Ori. x ER D . & & & & & $\begin{array}{l}-0.104 \star \\
(-2.56)\end{array}$ \\
\hline Constant & $\begin{array}{l}-1.402 \star \star \star \\
(-29.36)\end{array}$ & $\begin{array}{l}-1.406 \star \star \star \\
(-29.45)\end{array}$ & $\begin{array}{l}-1.404 \star \star \star \\
(-29.40)\end{array}$ & $\begin{array}{l}-1.406 \star \star \star \\
(-29.45)\end{array}$ & $\begin{array}{l}-1.338 \star \star \star \\
(-25.04)\end{array}$ \\
\hline Observations & 14914 & 14914 & 14914 & 14914 & 11159 \\
\hline
\end{tabular}

t statistics in parentheses

* $\mathrm{p}<0.05$, *ᄎ $\mathrm{p}<0.01$, *ᄎ* $\mathrm{p}<0.001$ 
Table A7: Banking Sector Efficiency, Competitiveness, and Net Saving

\begin{tabular}{|c|c|c|c|c|c|}
\hline & (1) & (2) & (3) & (4) & (5) \\
\hline L.net saving rate & $\begin{array}{l}0.169 \star \star \star \\
(14.52)\end{array}$ & $\begin{array}{l}0.0539 \star \star \\
(2.60)\end{array}$ & $\begin{array}{l}0.166 \star \star \star \\
(12.02)\end{array}$ & $\begin{array}{l}0.172 \star \star \star \\
(13.70)\end{array}$ & $\begin{array}{l}0.173 \star \star \star \\
(13.97)\end{array}$ \\
\hline L2. net saving rate & $\begin{array}{l}0.0286 \star \star \\
(2.99)\end{array}$ & $\begin{array}{l}-0.0275 \\
(-1.72)\end{array}$ & $\begin{array}{c}0.0191 \\
(1.69)\end{array}$ & $\begin{array}{l}0.0220 \star \\
(2.12)\end{array}$ & $\begin{array}{l}0.0287 \star \star \\
(2.90)\end{array}$ \\
\hline $\log$ asset & $\begin{array}{l}0.111 \star \star \star \\
(30.01)\end{array}$ & $\begin{array}{l}0.0880 \star \star \star \\
(15.62)\end{array}$ & $\begin{array}{l}0.110 \star \star \star \\
(24.01)\end{array}$ & $\begin{array}{l}0.109 \star \star \star \\
(26.82)\end{array}$ & $\begin{array}{l}0.105 \star \star \star \\
(27.87)\end{array}$ \\
\hline age quartile & $\begin{array}{l}-0.0214 k \star \star \\
(-3.96)\end{array}$ & $\begin{array}{l}-0.0330 \star \star \star \\
(-3.98)\end{array}$ & $\begin{array}{l}-0.0201 \star \star \\
(-3.16)\end{array}$ & $\begin{array}{l}-0.0202 \star \star \star \\
(-3.52)\end{array}$ & $\begin{array}{l}-0.0267 \star \star \star \\
(-4.93)\end{array}$ \\
\hline Tobin's $Q$ & $\begin{array}{c}-0.000120 \star \\
(-2.43)\end{array}$ & $\begin{array}{c}-0.000168 \\
(-1.44)\end{array}$ & $\begin{array}{c}-0.000123 \star \\
(-2.30)\end{array}$ & $\begin{array}{c}-0.000128 \star \\
(-2.53)\end{array}$ & $\begin{array}{c}-0.000128 \star \star \\
(-2.64)\end{array}$ \\
\hline industrial profit & $\begin{array}{l}0.328 \star \star \star \\
(15.00)\end{array}$ & $\begin{array}{l}0.257 \star \star \star \\
(4.74)\end{array}$ & $\begin{array}{l}0.322 \star \star \star \\
(13.15)\end{array}$ & $\begin{array}{l}0.314 \star \star \star \\
(13 \cdot 70)\end{array}$ & $\begin{array}{l}0.368 \star \star \star \\
(13 \cdot 34)\end{array}$ \\
\hline industrial profit^2 & $\begin{array}{l}-0.175 \star \star \star \\
(-15.60)\end{array}$ & $\begin{array}{l}-0.158 \star \star \star \\
(-8.73)\end{array}$ & $\begin{array}{l}-0.187 \star \star \star \\
(-15.19)\end{array}$ & $\begin{array}{l}-0.174 \star \star \star \\
(-15.08)\end{array}$ & $\begin{array}{l}-0.198 * \star \star \\
(-14.10)\end{array}$ \\
\hline Interest spread (B ) & $\begin{array}{l}0.0120 \star \star \star \\
(3.60)\end{array}$ & & & & \\
\hline H-statistic (Banks) & & $\begin{array}{l}-0.224 \star \star \star \\
(-4.95)\end{array}$ & & & \\
\hline Lerner index (Banks) & & & $\begin{array}{l}0.0453 \star \star \\
(3.11)\end{array}$ & & \\
\hline Boone indicator $(B \sim)$ & & & & $\begin{array}{l}-0.0217 \\
(-1.47)\end{array}$ & \\
\hline Concentration (Ban $\sim)$ & & & & & $\begin{array}{c}0.000504 \star \star \\
(2.61)\end{array}$ \\
\hline Constant & $\begin{array}{l}-1.485 \star \star \star \\
(-28.72)\end{array}$ & $\begin{array}{l}-0.959 \star \star \star \\
(-12.52)\end{array}$ & $\begin{array}{l}-1.445 \star \star \star \\
(-23.72)\end{array}$ & $\begin{array}{l}-1.406 \star \star \star \\
(-26.13)\end{array}$ & $\begin{array}{l}-1.392 \star \star \star \\
(-26.04)\end{array}$ \\
\hline Observations & 13884 & 3940 & 10038 & 11870 & 13139 \\
\hline
\end{tabular}

$t$ statistics in parentheses

$\star p<0.05$, *ᄎ $p<0.01, \star \star \star * p<0.001$ 
Table A8: Political Stability and Net Saving

\begin{tabular}{|c|c|c|}
\hline & (1) & $(2)$ \\
\hline L.net saving rate & $\begin{array}{l}0.177 \star \star \star \\
(15.83)\end{array}$ & $\begin{array}{l}0.178 \star \star \star \\
(15.85)\end{array}$ \\
\hline L2. net saving rate & $\begin{array}{l}0.0226 \star \\
(2.45)\end{array}$ & $\begin{array}{l}0.0228 \star \\
(2.47)\end{array}$ \\
\hline $\log$ asset & $\begin{array}{l}0.109 \star \star \star \\
(30.30)\end{array}$ & $\begin{array}{l}0.108 * \hbar \star \\
(30.18)\end{array}$ \\
\hline age quartile & $\begin{array}{l}-0.0224 \star \star \star \\
(-4.35)\end{array}$ & $\begin{array}{l}-0.0226 * \star \star \\
(-4.37)\end{array}$ \\
\hline Tobin's Q & $\begin{array}{c}-0.000132 \star \star \\
(-2.70)\end{array}$ & $\begin{array}{c}-0.000133 \star \star \\
(-2.70)\end{array}$ \\
\hline industrial profit & $\begin{array}{l}0.324 \star \star \star \\
(15.20)\end{array}$ & $\begin{array}{l}0.324 \star \star \star \\
(15.20)\end{array}$ \\
\hline industrial profit^2 & $\begin{array}{l}-0.173 \star \star \star \\
(-15.59)\end{array}$ & $\begin{array}{l}-0.173 \star \star \star \\
(-15.60)\end{array}$ \\
\hline Political Stability & $\begin{array}{c}-0.000854 \star \star \star \\
(-3.54)\end{array}$ & \\
\hline EFD x Poli. Stab. & & $\begin{array}{r}-0.0000167 \\
(-0.06)\end{array}$ \\
\hline Constant & $\begin{array}{l}-1.360 \star \star \star \\
(-27.58)\end{array}$ & $\begin{array}{l}-1.403 \star \star \star \\
(-29.07)\end{array}$ \\
\hline Observations & 14914 & 14914 \\
\hline
\end{tabular}

